\title{
Anatomy and Physiology of Multipolar Cells in the Rat Inferior Collicular Cortex Using the in vitro Brain Slice Technique
}

\author{
Philip H. Smith \\ Department of Anatomy, University of Wisconsin at Madison, Madison, Wisconsin 53706
}

\begin{abstract}
Coronal brain slices from 21-50-d-old hooded rats were used to characterize intracellular responses of cells in both the external and dorsal cortices of the inferior colliculus (IC). These cells could generate both sodium and calcium spikes. Depending on current amplitude, depolarizing current pulses could elicit either phasic or tonic firing patterns, with spike frequency adaptation. Spiking also occurred at the offset of a hyperpolarizing pulse. These patterns were due primarily to the activation of calcium conductances. Stimulation of the commissural pathway connecting the left and right IC produced a short-latency monosynaptic IPSP followed by an EPSP(s) and a late polysynaptic IPSP(s). Non-NMDA glutamate antagonists eliminated or reduced the amplitude of the EPSP and the late portion of the inhibition, while both IPSPs were blocked by $\mathrm{GABA}_{\mathrm{A}}$ antagonists. As described previously in guinea pig (Smith, 1986) and rat (Pierson et al., 1989), a large NMDA-mediated depolarizing event (paroxysmal depolarizing shift, or PDS) could be elicited by shocking the commissure of the $I C$ in the presence of picrotoxin or bicuculline, NMDA, 4-aminopyridine, or in $\mathbf{~ M g}^{2+}$ Ringer's. The picrotoxin-induced PDS was significantly reduced or abolished in Ringer's containing aminophosphonovalerate. Cells displaying the responses described were labeled with neurobiotin. Those labeled are medium-sized multipolar cells. Their dendrites are usually spiny and can extend superficially up to the cortical surface. Their thin axons give rise to collaterals that branch profusely within the cortex. The main axons project laterally along the circumference of the IC or medially into the commissure separating the collicular hemispheres.
\end{abstract}

The inferior colliculus (IC) is the principal component of the auditory midbrain and serves as a major integrative center within the auditory CNS. In the rat, parcellation schemes have subdivided this area based on cyto- and fibroachitectonic features (Faye-Lund and Osen, 1985) and to some extent on the afferent and efferent connections of certain regions (Ryugo, 1977; Hash-

\footnotetext{
Received Feb. 25, 1992; revised Apr. 16, 1992; accepted Apr. 21, 1992.

This work was generously supported by a FIRST grant from NIH (NS26285). I thank Lewis Haberly for the data collection and analysis software and the use of his setup to do preliminary experiments, John Harting for donating lab space, and Inge Siggelkow, Joan Meister, Jo Ann Ekleberry, Carol Dizack, and Terry Stewart for their technical assistance. Thanks also to Gail Robertson, Matt Banks, Philip Joris, and the anonymous reviewers for their useful comments on the manuscript.

Correspondence should be addressed to Philip H. Smith, Department of Anatomy, $51 \mathrm{H}$ Bardeen Labs, University of Wisconsin at Madison, Madison, WI 53706 .

Copyright (C) 1992 Society for Neuroscience $0270-6474 / 92 / 123700-16 \$ 05.00 / 0$
}

ikawa, 1983; Druga and Syka, 1984; Tokunaga et al., 1984; Faye-Lund, 1985, 1986; LeDoux et al., 1985, 1987, 1990a; Tanaka et al., 1985; Coleman and Clerici, 1987; Olazabal and Moore, 1989; Saldana, 1990; Vettcr and Saldana, 1990; Herbert et al., 1991). Based on Golgi, Nissl, and a combined cell-myelin method, Faye-Lund and Osen (1985) partitioned the rat IC into a core region, known as the central nucleus (ICC), and a shell or cortex region that surrounds the ICC.

One notion that has evolved is that the ICC and IC cortex function within two different pathways. The ICC is part of the lemniscal or tonotopic pathway. In this pathway, frequencies represented along the length of the cochlear partition are mapped in a precise fashion onto auditory nuclei, and the projection of fibers from one nucleus onto the next, up the auditory pathway, maintains this tonotopic configuration. This system is believed to be of importance in the processing of spatial and spectral information.

In contrast to the $I C C$, the cortices of the IC function within the extralemniscal or diffuse system. These regions of the colliculus have becn implicated as a vital component of the circuitry involved in the initiation of both genetically transmitted and ethanol withdrawal-induced reflexive audiogenic seizures (see Frye et al., 1983, 1986; Browning, 1986), the visceral/emotional responses to acoustic stimuli (LeDoux et al., 1985, 1986, 1988, 1990a,b; Iwada et al., 1986a,b), and the reflexive orienting responses of the pinnae, eye, head, and body evoked by sound (see Aitkin, 1985). The cortex is a laminated structure consisting of three layers and may be divided into an external cortex (EC), which wraps around the ICC laterally, ventrally, rostrally, and ventrocaudally, and a dorsal cortex (DC) situated dorsocaudally and dorsomedially to the ICC. As the name "extralemniscal" implies, the primary inputs to the IC cortex are not direct projections from the tonotopically arranged nuclei of the brainstem via the lateral lemniscus (LL). Rather, auditory inputs are more indirect, arising from cells in the ICC and contralateral cortex of the IC (Tokunaga et al., 1984; Colcman and Clcrici, 1987) and from auditory cerebral cortical areas AI, AII, and AAF (Faye-Lund, 1985, 1986; Coleman and Clerici, 1987; Games and Winer, 1988; Herbert et al., 1991). In addition, certain areas of the IC cortex receive inputs from regions not directly associated with auditory function. In particular, somatosensory inputs to the external nucleus from nuclei cuneatus and gracilus as well as the spinal nucleus of the trigeminal have been reported. Inputs from the deep superior colliculus, parabrachial nucleus, and substantia nigra pars lateralis have also been noted (Tokunaga et al., 1984; Coleman and Clerici, 1987; Olazabel and Moore, 1989) as well as direct projections from the globis pallidus (Yasui et al., 1990) and the posterior hypothalamus (Inagaki et al., 1990). 
In vivo physiology from the rat $\mathrm{IC}$ is confined primarily to cells located in the ICC (Clopton and Winfield, 1973; Reale and Glaser, 1975; Clopton and Silverman, 1977; Silverman and Clopton, 1977; Farley et al., 1982; Moller and Rees, 1986; Faingold et al., 1989; Poon et al., 1990, 1991), and reports of responses from IC cortical cells are typically anecdotal in nature. Responses from IC cortical cells in other species are described as sluggish, easily habituated, and broadly tuned to auditory stimuli (see Aitkin, 1985). In some cases, cells in the EC would also or exclusively respond to somatosensory stimulation in a similar fashion. Besides a preliminary report from this lab (Smith, 1986), only one report of recordings from cells in the IC slice has appeared (Pierson et al., 1989). In these experiments, responses to current injection were not described and the shock stimulation used to evoke synaptic potentials was applied to the immediate vicinity of the cell so the potential source of the synaptic input was unknown. In addition, morphology of the cells was not described. In order to elucidate the circuitry of the IC cortex, I have begun to characterize cells in this region in terms of their basic response properties, the transmitters used at their inputs, and the morphological features of the soma, dendritic tree, and local axon collateral systems.

\section{Materials and Methods}

Tissue preparation. Brain slices were prepared in two ways. In both cases, hooded rats (Harlan Sprague-Dawley) from 21 to $50 \mathrm{~d}$ old were used. In the first procedure, rats were anesthetized with ether and decapitated. A transverse cut was made through the brain immediately rostral to the superior colliculus, and the caudal half of the brain was removed and immersed in cold, oxygenated Ringer's. A second transverse cut was made in the removed block approximately half way along the rostrocaudal extent of the cerebellum, and the region caudal to this was discarded. The remaining portion of the block was mounted with Super Glue, colliculus end up, in a chamber and immersed with cold, oxygenated Ringer's. Slices, $400 \mu \mathrm{m}$ thick, were then cut using a series 1000 Vibratome. The first few slices containing the superior colliculus and underlying midbrain tegmentum were discarded. Subsequent slices, containing the inferior colliculus, were carefully placed in individual vials containing continuously oxygenated Ringer's at room temperature.

In the second procedure, rats were anesthetized to an areflexive state with either sodium pentobarbital $(40 \mathrm{mg} / \mathrm{kg}$, i.p.) or chloral hydrate $(42$ $\mathrm{mg} / 100 \mathrm{gm}$ body weight, i.p.). The animal was then perfused intracardially with cold, oxygenated Ringer's solution where $\mathrm{NaCl}$ had been replaced with sucrose (Aghajanian and Rasmussen, 1989). The animals were then decapitated, and $400 \mu \mathrm{m}$ slices were taken in the same fashion as described in the first procedure with the exception that the saline used during the dissection and vibratoming was the modified form.

The appropriate slice was transferred to a recording chamber, modified from the dual subchamber design of Nicoll and Alger (1981), where the slice was sandwiched between two layers of nylon mesh for doublesided perfusion. " $\Lambda$ ppropriate" slices were determined by the following criteria. Typically, three to four $400 \mu \mathrm{m}$ slices, in the coronal plane, would encompass the entire inferior colliculus. The most rostral slice would usually include some of the caudal aspect of the superior colliculus as well and was not used. In the caudalmost slice, the right and left IC were usually not connected by a commissure (CoIC), being separated by the subarachnoid space and folia of the cerebellum. Because the commissure is a major source of stimulated synaptic input, this slice was typically not used. The middle two slices were usually of sufficient thickness to include some of the commissural fibers, the dorsal and/or the external cortices, and some of the lateral lemniscal fibers and the central nucleus. One or both of these middle slices was typically used. Oxygenated Ringer's perfusing through the chamber was gradually raised from room temperature to $33-34^{\circ} \mathrm{C}$ and the temperature monitored with a thermocouple probe (Fluke Instruments). The slice was perfused at a rate of $2.5 \mathrm{ml} / \mathrm{min}$ with a bathing medium that consisted of the following (in $\mathrm{mM}$ ): $\mathrm{NaCl}, 124 ; \mathrm{KCl}, 5 ; \mathrm{KH}_{2} \mathrm{PO}_{4}, 1.2 ; \mathrm{CaCl}_{2}, 2.4 ; \mathrm{MgSO}_{4}$, 1.3; $\mathrm{NaHCO}_{3}, 26$; and glucose, 10 ; saturated with $95 \% \mathrm{O}_{2}, 5 \% \mathrm{CO}_{2} ; \mathrm{pH}$ 7.4. In some experiments, where $0 \mathrm{Mg}^{2+}$ Ringer's was used, sodium sulfate was substituted for magnesium sulfate. Calcium-free saline was made by replacing $\mathrm{Ca}^{2+}$ with $\mathrm{Mg}^{2+}$.

Recording and data collection. The results reported here were obtained from recordings from 53 cclls in 39 slices taken from 32 rats. Twentysix of these cells were recorded from with electrodes filled with neurobiotin and were subsequently injected and recovered. Intracellular recordings were made using a Neurodata dual-channel intracellular recording amplifier. Microelectrodes were pulled on a Flaming-Brown P87 micropipette puller and filled with either $4 \mathrm{M}$ potassium acetate or a $2 \%$ solution of biocytin (Sigma Chemical) or neurobiotin (Vector Labs) in $2 \mathrm{M}$ potassium acetate buffered to $\mathrm{pH} 7.4$ with acetic acid. Electrode impedances ranged from 110 to $150 \mathrm{M} \Omega$.

Typically, one set of bipolar stimulating electrodes made from insulated tungsten microelectrodes (tip impedance, $5 \mathrm{M} \Omega$; tips spaced 200 $\mu \mathrm{m}$ apart) was placed in the fibers of the lateral lemniscus (LL) just ventral to their entry into the IC. A second set was placed in the fibers of the commissure of the IC (CoIC), at the midline or on the opposite side relative to the location of the LL stimulating clcctrodes and the intracellular electrode. Shock stimuli were typically $100 \mu \mathrm{sec}$ in duration.

Intracellular current and voltage records were digitized and the two channels sampled by a Compaq Deskpro 386s or Northgate 486 using software developed here. Data were either analyzed on line or stored on optical disk (IBM 3363) for later analysis. Current-voltage plots were generated using software developed here. Typically, the averaged membrane potential was measured $130-180 \mathrm{msec}$ after the onset of $200 \mathrm{msec}$ current pulses of different amplitudes and polarity. The deflection of the membrane potential relative to the resting potential was plotted versus the amount of current injected. The input resistance of the cell was taken to be the slope of the linear regression line drawn through these points.

Histology. Following recording and injection of biocytin or neurobiotin, the slice was carefully removed from the recording chamber and fixed in fresh $4 \%$ paraformaldehyde. The slice was then cryoprotected, by passage through a series of glycerol-sucrose solutions, and $60 \mu \mathrm{m}$ frozen sections collected and washed in $0.1 \mathrm{M}$ phosphate buffer, $\mathrm{pH}$ 7.4. The sections were then incubated for $20 \mathrm{~min}$ in $0.5 \% \mathrm{H}_{2} \mathrm{O}_{2}$ in phosphate buffer, rinsed in phosphate-buffered saline, and then incubated overnight in the avidin-biotin-HRP complex (ABC Kit, Vector Labs). The following day, the sections were rinsed in phosphate buffer and the HRP reacted using the diaminobenzidine (DAB)-nickel/cobalt intensification method (Adams, 1981), and then mounted, counterstained with cresyl violet, and coverslipped. Following recordings using KAc-filled electrodes, the shaft of the electrode was pushed through the slice recording site, creating a small hole. The slice was then fixed and cryoprotected, sectioned, mounted, counterstained with cresyl violet, and coverslipped. The location of the hole indicating the recording site was noted relative to the boundaries of the inferior colliculus.

Two-dimensional drawings of injected cells were made using a camera lucida attached to a Zeiss microscope. The location of the cell body relative to the divisions of the rat inferior colliculus was determined using the descriptions of Faye-Lund and Osen (1985).

\section{Results}

Physiology

Intrinsic properties. The cells of the IC cortex that will be reported on here had similar physiological properties. Others, not described in this article, showed different synaptic and spike response.

These cells typically had resting potential around $-60 \mathrm{mV}$ (range, -53 to $-79 \mathrm{mV}$; mean, $-62.7 \mathrm{mV}$ ) and steady state input resistances ranging from 31 to $113 \mathrm{M} \Omega$ (mean, $58.5 \mathrm{M} \Omega$ ). Often, at some level of depolarization above rest, a "hump" developed at the onset of the deflection and the transient $I-V$ curve, derived from this region displayed an expansive nonlinearity (Fig. $1 A, B$ ). This hump appeared to result from the activation of a calcium conductance. In three cells tested, when sodium spikes were blocked with TTX and potassium conductances depressed with tetraethylammonium (TEA), the hump was still apparent in normal saline (Fig. $1 B$, top panel, asterisk). If calcium was then removed from the bath, depolarizing pulses no longer elicited the hump even at higher levels of depolariza- 


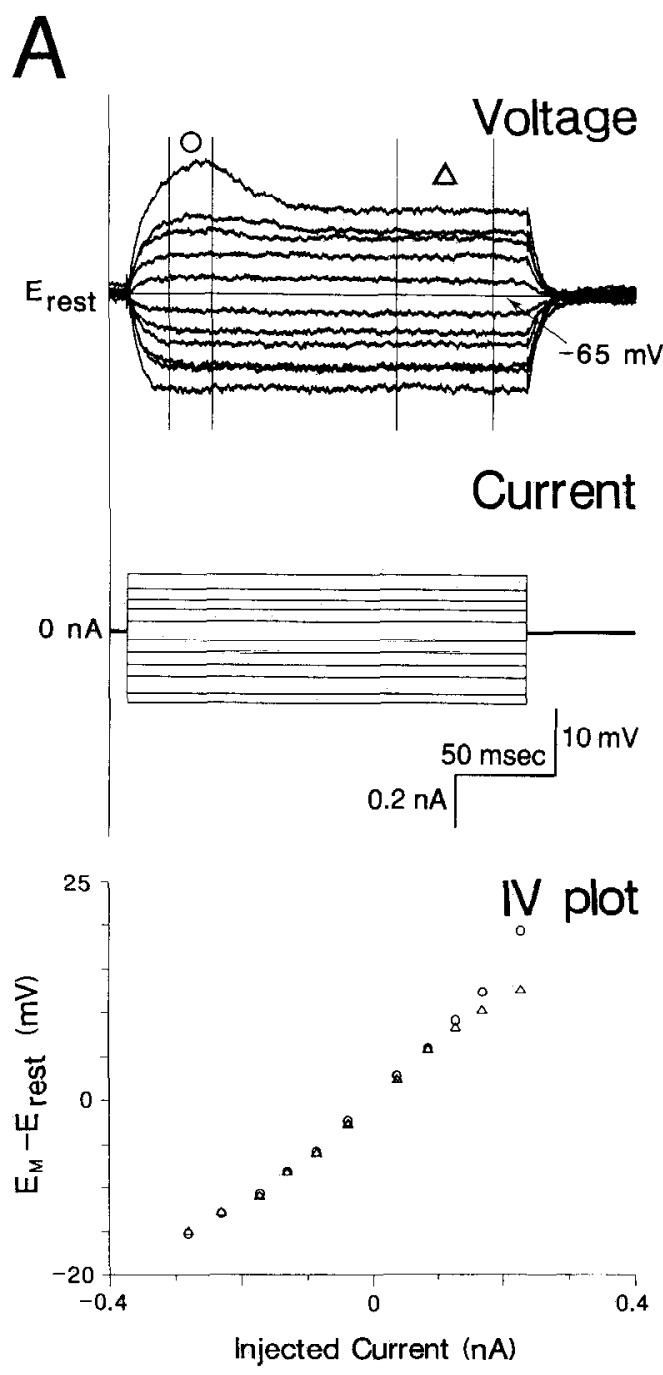

B

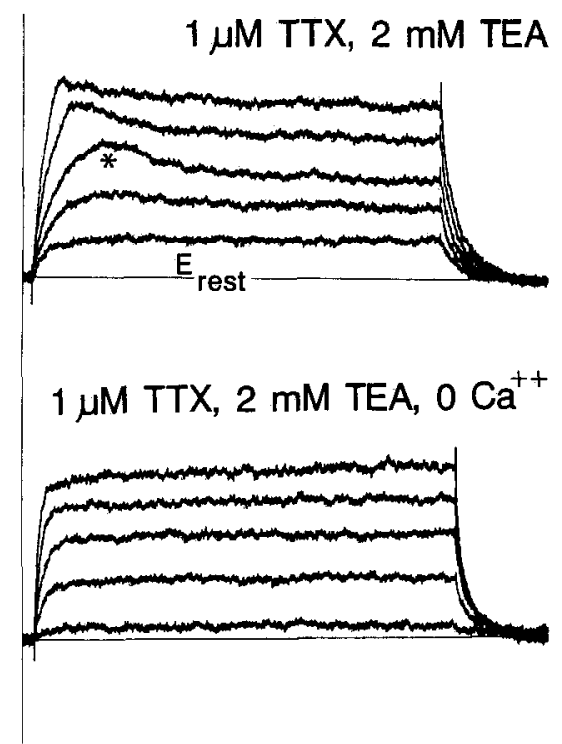

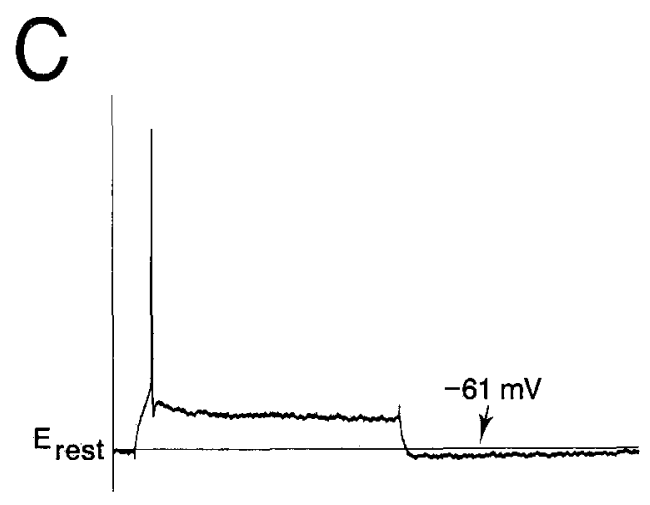
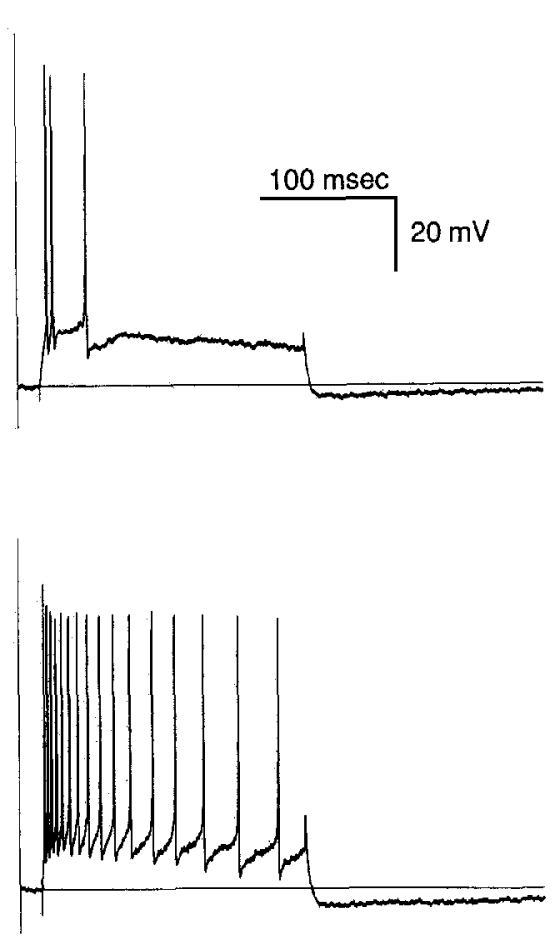

D

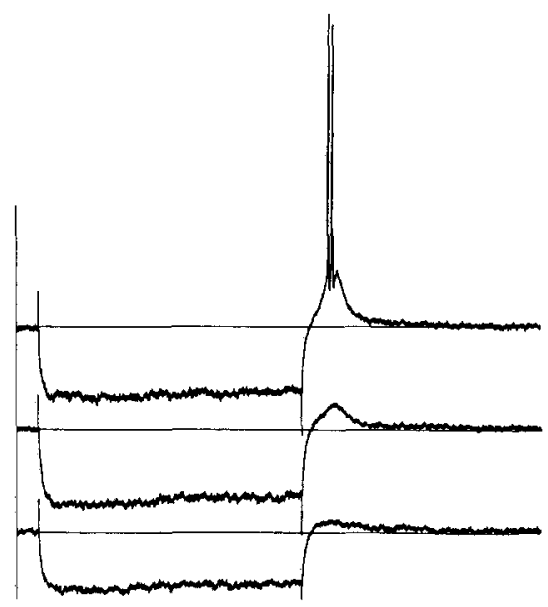

Figure 1. Intrinsic membrane features. A, Voltage deflections of the cell membrane (Voltage) in response to the 200 msec current pulses (Current). Areas in the top traces enclosed by the lines indicate the portions of the data that were averaged to derive the two $I-V$ plots seen below. The $I-V$ plot derived from measurements at the onset of the response is represented by the open circles, and during the sustained portion, by the triangles. $E_{M}$, the averaged voltage over the areas of the voltage traces enclosed by the lines. $B, \mathrm{Ca}^{2+}$ dependence of initial nonlinearity. Upper traces, Responses to five depolarizing current pulses in saline containing TTX/TEA to show the onset of the hump (asterisk) at a level above the resting potential. Lower traces, Responses of the same cell to five depolarizing pulses in $\mathrm{O} \mathrm{Ca}^{2+}$ saline containing TTX/TEA. $C$, Spike response of another cell to $200 \mathrm{msec}$ depolarizing current pulses of increasing intensity to illustrate the transient response at lower current levels (top two traces) and the sustained response at higher levels (lower trace). $D$, Offset depolarization and spiking after hyperpolarizing pulses of increasing amplitude (bottom to top). Calibrations in $A$ apply to $A$ and $B$; calihrations in $C$ apply to $C$ and $D$. 
A

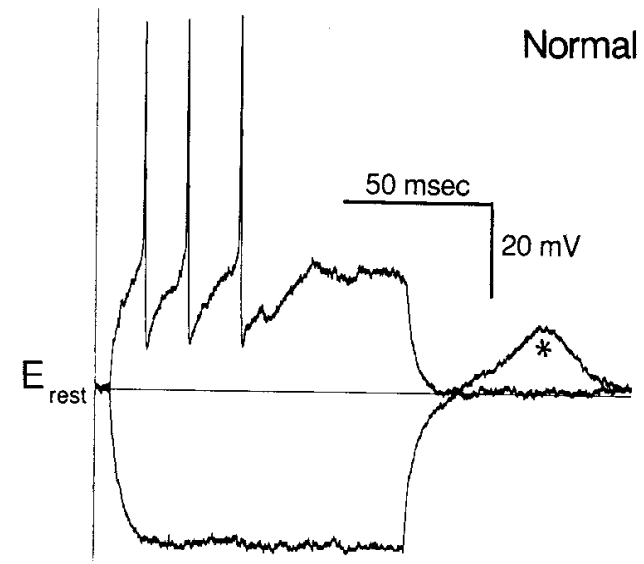

B

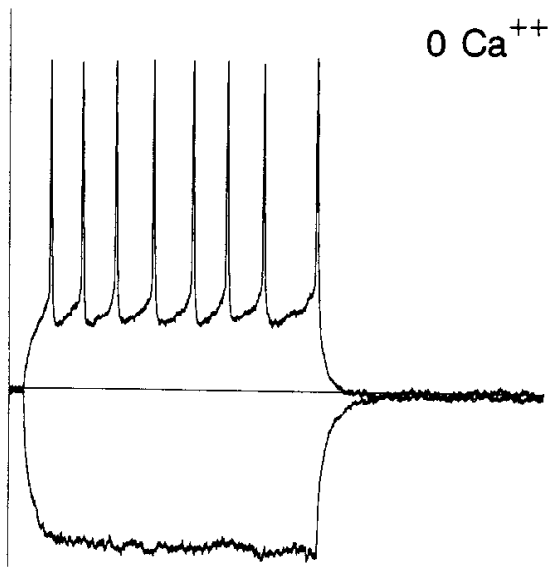

C

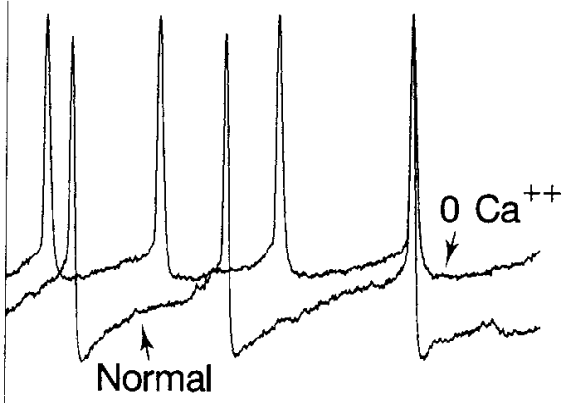

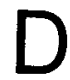
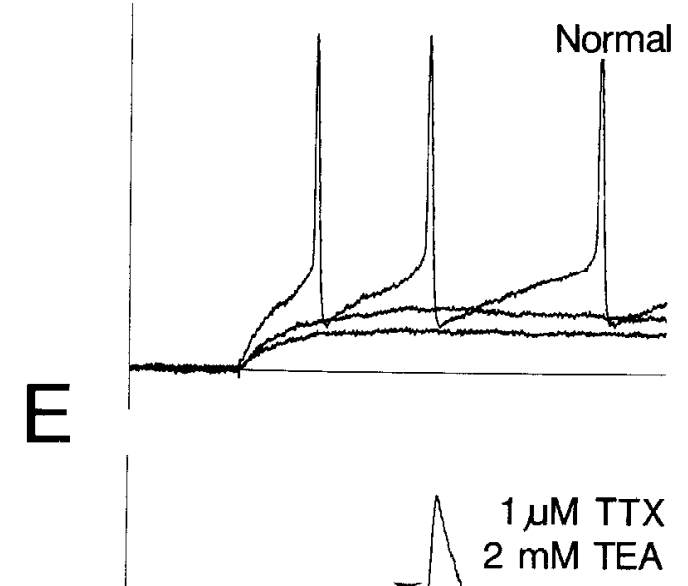

E

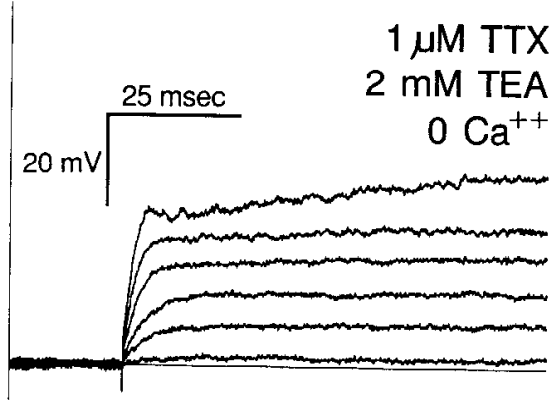

G

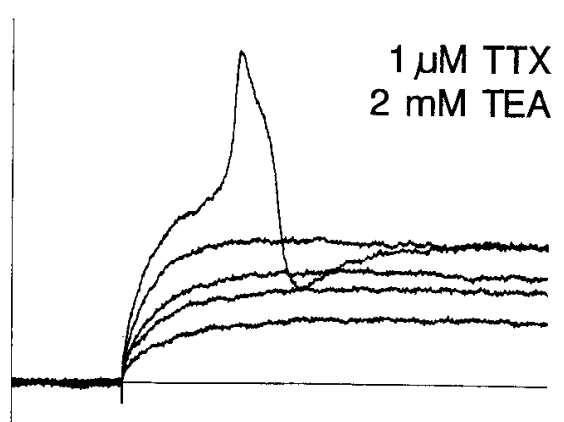

Figure 2. $\mathrm{Ca}^{2+}$-dependent features. A, Transient firing behavior to a depolarizing current pulse and rebound depolarization (asterisk) at the offset of a hyperpolarizing current pulse. $B$, Response of the same cell to the same-amplitude hyperpolarizing current pulse and a smaller-amplitude depolarizing pulse in $\mathrm{OCa}^{2+}$ saline. $C$, Action potentials seen in $A$ and $B$ on a different time scale to illustrate the difference in the afterhyperpolarization and the slight increase in action potential duration in $0 \mathrm{Ca}^{2+}$. DC level of the $0 \mathrm{Ca}^{++}$trace has been shifted slightly upward for clarity. $D-G$, Calcium spikes. $D$, Initial portion of the responses to 3-200 msec current pulse of increasing amplitude, with the highest-amplitude pulse generating three sodium spikes. $E$, Initial portion of the responses of the same cell to six current pulses of increasing intensity after the cell was bathed in TTX/TEA, showing not only the hump at the onset of the third and fourth pulses (asterisk) but a Ca ${ }^{2+}$ spike at the highest level (arrow). $F$, Responses to six current pulses in saline where $\mathrm{Ca}^{2+}$ was replaced with $\mathrm{Mg}^{2+}$, showing disappearance of the onset hump and the Ca ${ }^{2+}$ spike. $G$, Response to five current pulses after return to normal saline containing TTX and TEA. Calibrations in $A$ apply to $A$ and $B$; calibrations in $F$ apply to $C-G$.

tion (Fig. 1B, bottom panel). This effect was reversible. Sodium action potentials were typically overshooting (mean amplitude, $63 \mathrm{mV}$ above the level of depolarization required to elicit a spike), and the afterhyperpolarizations, following each action potential, were biphasic with a fast and a slow component (Fig. 1C). Spontaneous sodium spike activity, in the absence of shock stimulation, was rarely observed.

It was often possible to initiate transient firing at the onset of 


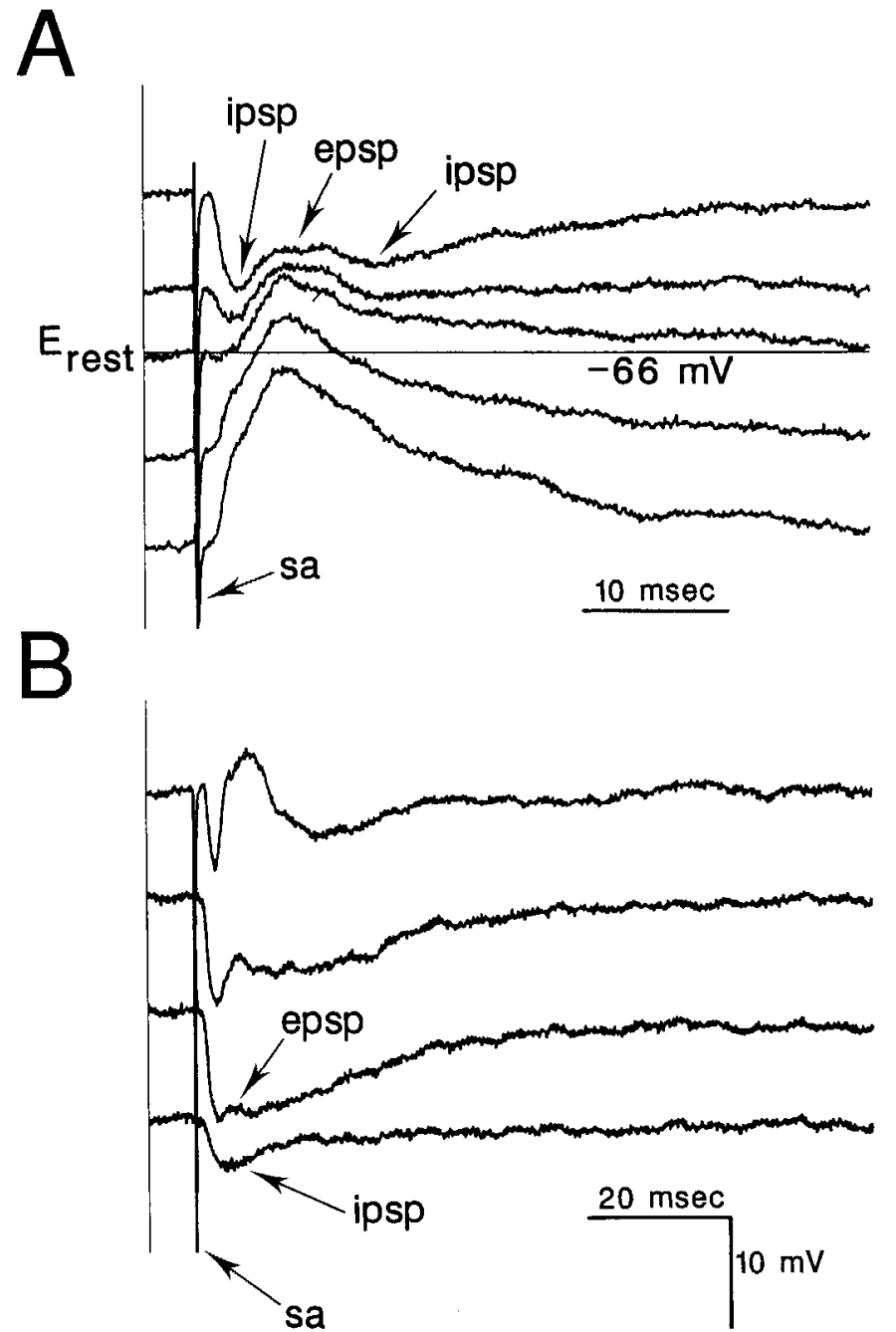

Figure 3. Commissural inputs. A, Synaptic response to the same amplitude shock stimulation ( $s a$, shock artifact) of the CoIC at the cell's resting potential $\left(E_{\text {rest }}=-66 \mathrm{mV}\right)$ and with the cell artificially polarized above and below rest. $B$, Synaptic response of the same cell to progressively increasing shock strengths (bottom to top) applied to the commissural connection. Voltage calibration in $B$ applies to $A$ and $B$.

low-amplitude depolarization (Fig. $1 C$, top panels). With increased levels of current, it was possible to elicit a sustained response for the duration of the pulse although spike rate adaptation was clearly evident (Fig. $1 C$, bottom panel). In addition, the cells would often show a pronounced offset response or rebound excitation (Fig. $1 D$ ) at the offset of a hyperpolarizing pulse of sufficicnt amplitude, where the membrane potential would overshoot the resting potential, sometimes for durations of 50-100 msec, and could elicit one to five spikes.

Cells were bathed in $0 \mathrm{Ca}^{2+}$ saline to test whether the calciumdependent "hump," seen at the onset of a subthreshold pulse, could account for any of these observed response features. In five cases tested, the "hump" and the tendency to fire transiently at the onset of a small amplitude depolarization were significantly reduced, as was the depolarization elicited at the offset of a hyperpolarizing pulse (Fig. $2 A, B$ ). In addition, the configuration of the spike afterhyperpolarization was altered, and spike frequency adaptation, seen at higher levels of depolarization, was significantly reduced (Fig. $2 A-C$ ). The change in the configuration of the afterhyperpolarization and loss of adaptation
A

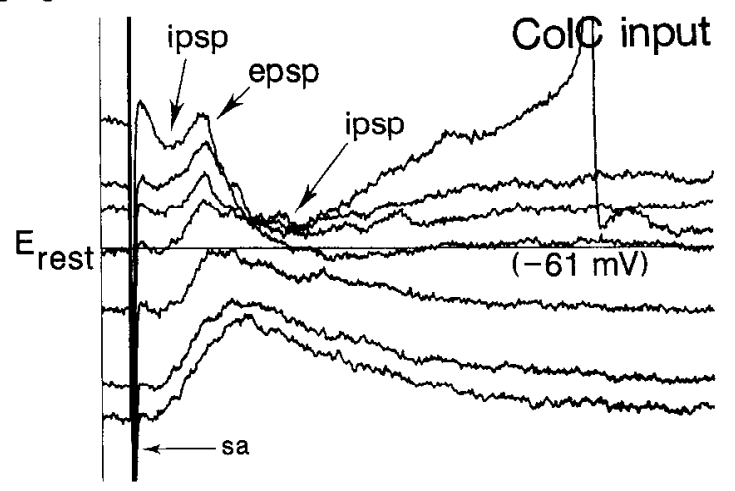

Q

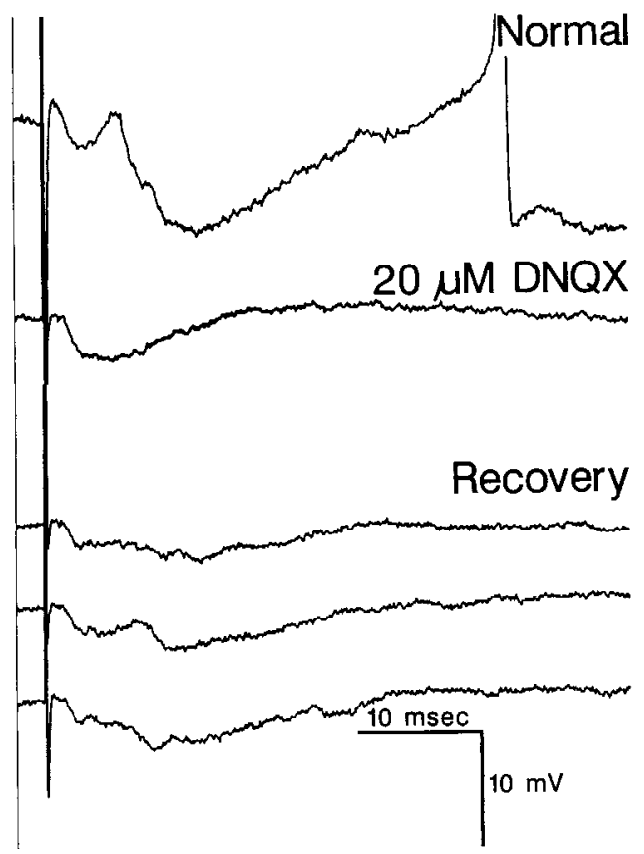

Figure 4. Glutaminergic nature of the EPSP. $A$, Synaptic response to CoIC stimulation with the cell membrane potential polarized to different levels with respect to the resting potential $\left(E_{\text {res }}\right)$. sa, shock artifact. $B$ : Upper trace, Normal synaptic response of the cell shown in $A$. Second trace, Synaptic response to the same shock stimulation after bath application of DNQX showing the total absence of the EPSP (even at higher shock strength) and later IPSPs. Lower three traces, Onset of recovery of the EPSP and late IPSPs $20 \mathrm{~min}$ after return to normal saline. Calibration in $B$ applies to $A$ and $B$.

indicated the presence of a calcium-activated potassium component. These cells could also generate $\mathrm{Ca}^{2+}$ spikes (Fig. $2 D-$ $G)$. In three of four cases tested, under bath conditions where sodium spikes were blocked (TTX/TEA), depolarizing the cell could generate a long slow spike (Fig. $2 E$, arrow) that was reversibly eliminated in saline with no calcium (Fig. $2 F, G$ ).

Synaptic responses. When recording from these cells in the absence of any shock stimulation to potential sources of synaptic input, spontaneous synaptic events were rarely seen.

Stimulation of the CoIC, which connects the two sides of the IC and provides the major axonal input to this area, elicited a characteristic IPSP/EPSP/IPSP sequence of synaptic events. At the typical resting potential of the cell, IPSPs were almost always difficult to distinguish or were depolarizing presumably because 
the reversal potential of the mediating ion was close to the cell's resting potential. It was therefore necessary to change the cell's membrane potential, with respect to the resting potential, to distinguish IPSPs from EPSPs (Fig. 3A). Pharmacological experiments indicate that the IPSP can be divided into early direct and late polysynaptic components for reasons that will be described below. CoIC stimulation of sufficient magnitude usually generated an IPSP with an onset occurring around $1.5 \mathrm{msec}$ after the shock (mean, $1.56 \mathrm{msec}$; range, $0.9-4 \mathrm{msec}$ ). Inhibitory events typically persisted for 25-35 msec (measured from the shock artifact to the point where the membrane potential returned to prestimulus DC levels; mean, $31 \mathrm{msec}$; range, 12.7$50 \mathrm{msec})$. The inhibition often showed a lower threshold to shock stimulation (Fig. $3 B$ ). At higher shock strengths, the onset of the inhibition was quickly followed by an EPSP, or multiple EPSPs. At rest, the EPSP was rarely suprathreshold even at high shock strengths. The latency of the EPSP was difficult to discern because it occurred during the preceding IPSP. However, the first indication of a positive-going potential was usually initiated around $4 \mathrm{msec}$ after the shock (mean, $3.9 \mathrm{msec}$; range, 2.1-11 $\mathrm{msec}$ ). The duration of EPSP was also hard to distinguish because it was surrounded by inhibitory currents and could vary considerably with stimulus intensity. If the cell was depolarized, the EPSP would usually be of sufficient magnitude and duration to generate a single spike. Occasionally, at higher shock strengths, the duration of the EPSP(s) was sufficient to evoke multiple action potentials.

Responses to shock stimulation of other potential sources of input to the cortex were not as consistent. A second major input pathway to the IC is the LL, but in most of the cells tested, stimulation of the LL elicited no synaptic events or events of minimal amplitude. When seen, synaptic potentials could be of cither sign and usually occurred at much higher shock strengths with much longer and more variable latency from trial to trial. There did appear to be a tendency for cells situated more laterally, in the EC, to be more likely to show synaptic input from LL stimulation.

In most cases tested (16 of 20), shock stimulation of the ICC generated short-latency synaptic events, but as with the LLinduced events, these were quite variable from cell to cell. In contrast to stimulation of the CoIC and LL, such stimulation may directly activate not only axons but cell bodies in the vicinity of the stimulating electrode, which could explain such variability.

Pharmacology. Bath application of antagonists was used to determine the nature of the excitatory neurotransmitter used in the system activated by the stimulation of the CoIC. In six cases tested, the specific non-NMDA receptor antagonists 6,7-dinitroquinoxaline-2,3-dionc (DNQX) (Fig. 4A,B) or 6-cyano-7dinitroquinoxaline-2,3-dione (CNQX) (not shown) completely eliminated the EPSP. In five cases tested, kynurenic acid, a relatively nonspecific glutamate antagonist, significantly reduced the amplitude of the EPSP (not shown). Not only was the excitatory input eliminated, but the later component of the inhibitory input also disappeared, leaving the early portion intact (Fig. 4B). The loss of the EPSP indicates that it is generated by activation of non-NMDA-type glutamate receptors. The loss of the late inhibitory events indicates that the glutaminergic input, driven by electrical stimulation of the CoIC, excites not only this cell, but inhibitory interneurons that provide the late inhibition to the impaled cell as well. The early inhibition presumably remains because it is a direct input.

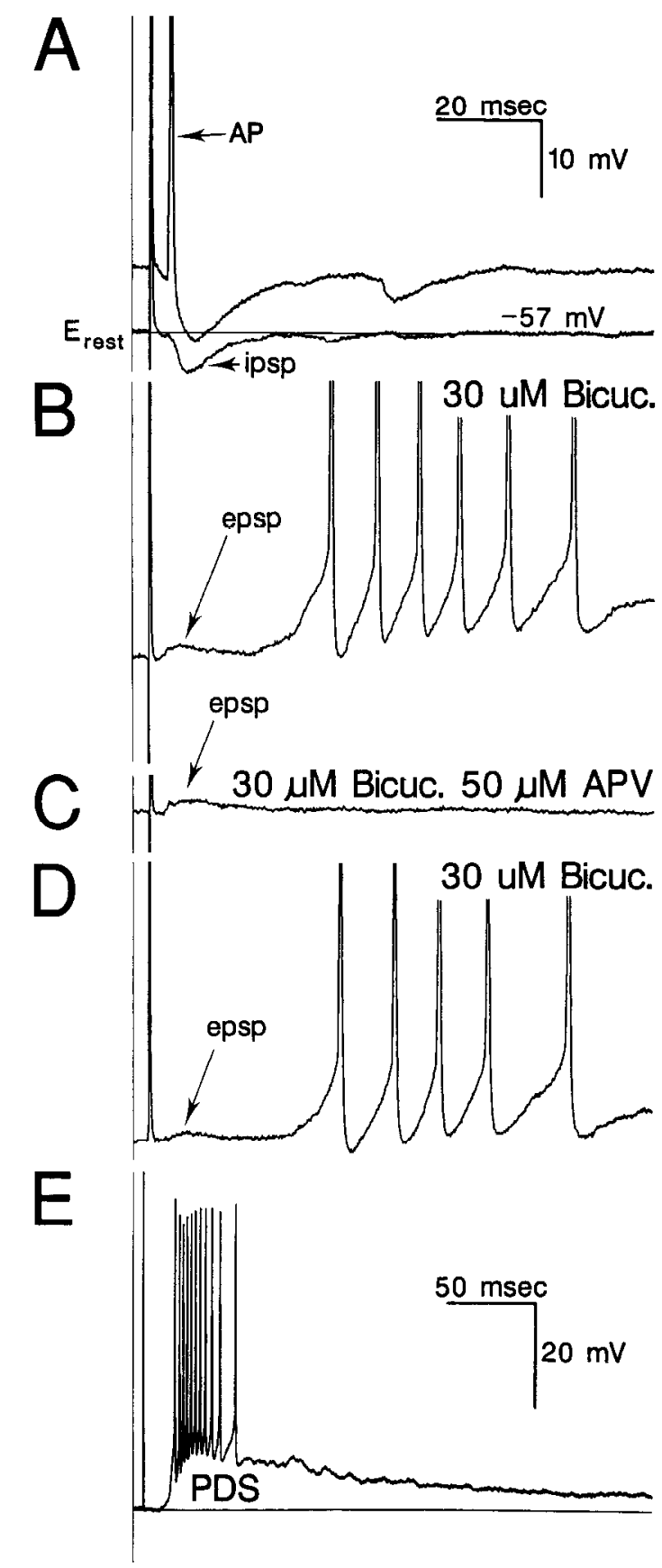

Figure 5. GABAergic nature of the IPSPs. $A$, Synaptic response to CoIC stimulation at resting potential $\left(E_{\text {ress }}\right.$, lower trace). Depolarizing the cell (upper trace) reveals the early IPSP and makes the EPSP suprathrcshold $(A P)$. $B$, Synaptic response of the same cell to the same shock strength after bath application of bicuculline shows a complete block of inhibition, reveals the EPSP, and generates a large suprathreshold PDS. $C$, Synaptic response to the same shock stimulation after addition of APV shows a maintenance of the EPSP but a block of the PDS. $D$, Recovery of the PDS after removal of APV from the bath. $E$, Shock-induced PDS on different time and voltage scales. Calibration in $A$ applies to $A-D$.

I also sought to determine the transmitter responsible for the inhibitory synaptic events. In five cases tested, the glycine antagonist strychnine $(1 \mu \mathrm{M})$ had no apparent effect on the IPSPs. In contrast, in 15 cases, the $\mathrm{GABA}_{\mathrm{A}}$ receptor antagonist bicuculline or picrotoxin blocked the described inhibitory events elicited by stimulation of the CoIC (Fig. $5 A, B$ ), exposing the 
Figure 6. Other evidence for NMDA receptors. $A$, Synaptic response to $\mathrm{CoIC}$ stimulation with cell polarized to different DC levels. $B$, Response of the same cell to CoIC stimulation when bathed in Ringer's containing no magnesium. $C$, Same record as in $B$ on different time and voltage scales. $D$, Synaptic response of the same cell, with the membrane depolarized, at a shock level below the threshold for the PDS, to reveal the intact IPSP/EPSP/IPSP sequence. $E$, Response of another cell to CoIC stimulation during bath application of NMDA. $F$, Same record as in $E$ on different time and intensity scales. $s a$, shock artifact. Calibration in $D$ applies to $A, B, D$, and $E$; calibration in $F$ applies to $C$ and $F$.
A
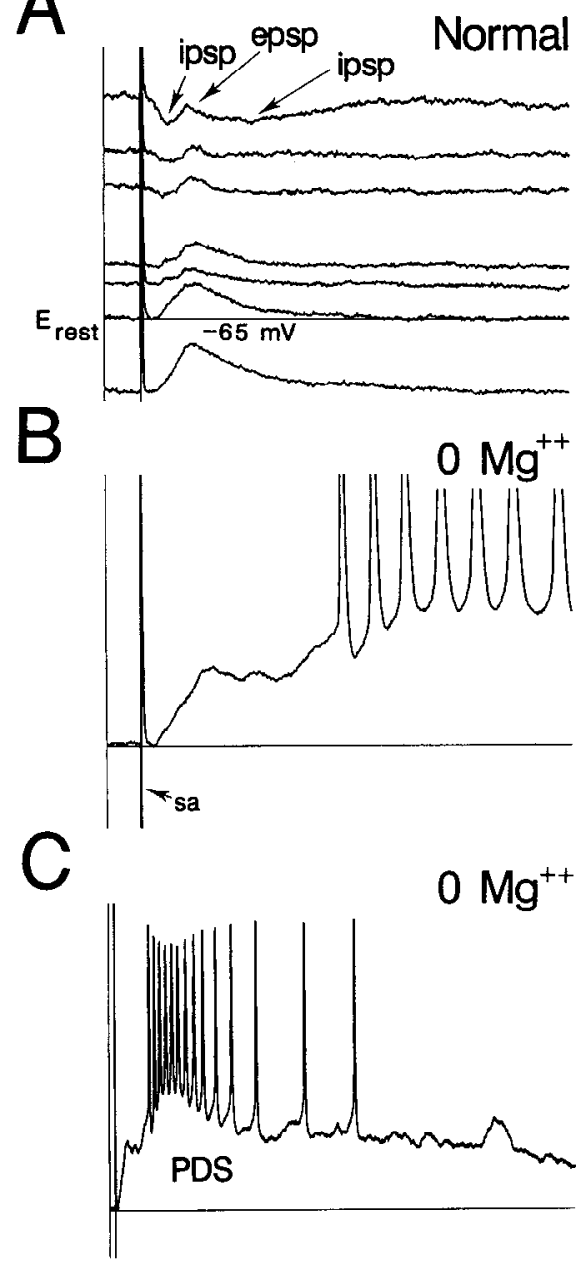
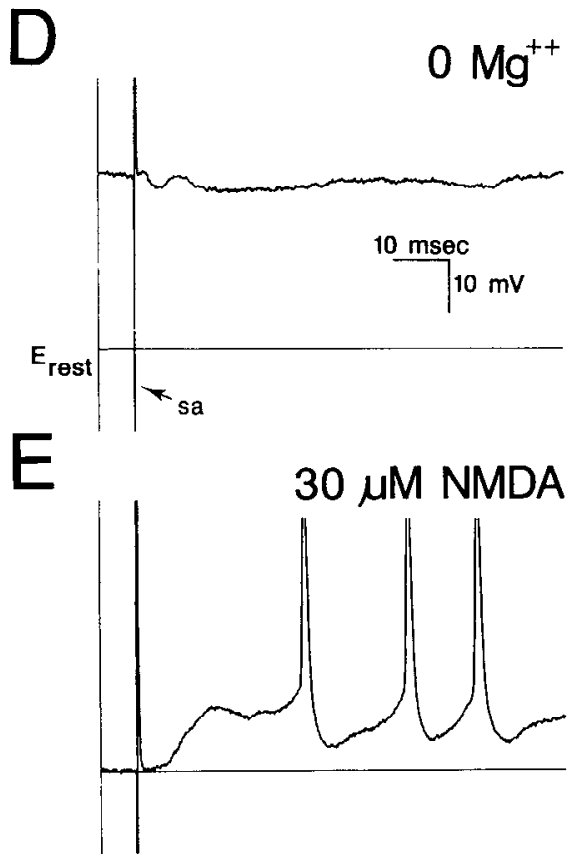

$30 \mu \mathrm{M} N \mathrm{NDA}$

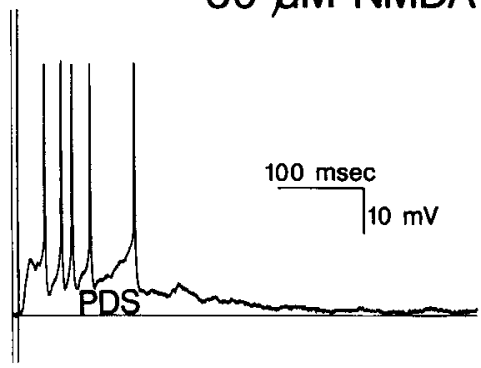

EPSP. In the presence of a GABA antagonist, CoIC stimulation would also generate very large suprathreshold membrane depolarizations (Fig. $5 B, D$ ) lasting up to $400 \mathrm{msec}$ (Fig. 5E). These potentials strongly resemble the synaptically generated paroxysmal depolarizing shifts (PDSs) that have been described in the cortex and hippocampus when GABA inhibition has been compromised (Schwartzkroin and Prince, 1980; Gutnick et al., 1982).

The PDS responses are due to the activation of NMDA receptors. In five cases tested, addition of the selective NMDA receptor antagonist aminophosphonovalerate (APV) to the bath, subsequent to addition of a GABA antagonist, caused CoICgenerated PDS activity to diminish (Fig. $5 \mathrm{C}$ ) while not significantly affecting the early excitatory event. This experiment indicates that, if GABA inhibition is compromised, stimulation of the CoIC acts to generate paroxysmal depolarizations through an NMDA-mediated process. The persistence of the early EPSP, in APV, also reinforces the notion that this synaptic event is glutaminergic but not mediated by NMDA receptors.

Other methods of NMDA receptor activation also elicited PDS activity in response to commissural stimulation. In six cases tested, removal of magnesium ions, known to block NMDA receptors in a voltage-dependent fashion (Coan and Collingridge, 1985), caused the cell to respond to CoIC shock stimulation with a PDS (Fig. 6A-C). This was despite the fact that the GABA inhibition was still intact (Fig. 6D). In addition, direct bath application of NMDA alone facilitated a PDS-like event in three cases (Fig. $6 E, F$ ). It was also possible to evoke PDS behavior using the potassium channel antagonist 4-aminopyridine (4-AP). In four cases tested, application of 1-2 mM 4-AP dramatically increased observed spontaneous synaptic events and blocked the early component of the spike afterhyperpolarization (Fig. $7 A-F$ ). Shock stimulation of the CoIC in 4-AP could elicit a PDS or cause prolonged repetitive firing (Fig. $7 G, H$ ).

Under the conditions described above, where PDS activity could be elicited by stimulation of the commissural connection, it was also possible to elicit a similar response from stimulation of the ICC (Fig. $8 D-F$ ). In contrast, it was rarely ( 2 of 12 cases tested) possible (Fig. $8 A-C$ ) to elicit such a PDS by stimulation of the LL. PDS activity was never observed in records from cells under "normal" slice conditions. Tetanic stimulation (up to $250 \mathrm{~Hz}$ ) of the described inputs or stimulation of synaptic inputs while the cell was depolarized was also unable to elicit abnormal behavior under normal conditions.

\section{Anatomy}

The injected cells were located in the dorsal, cortical aspect of the colliculus. In the more rostral slices (see Materials and Methods), where the EC completely occupies the dorsal IC surface, cells were always in the dorsal half of the cortex. In more caudal slices, where the DC occupies the medial aspect and EC the lateral aspect of the dorsal IC surface, cells were either in the 
A

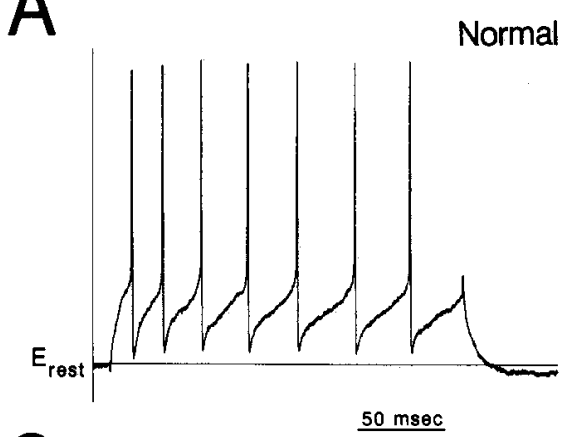

C

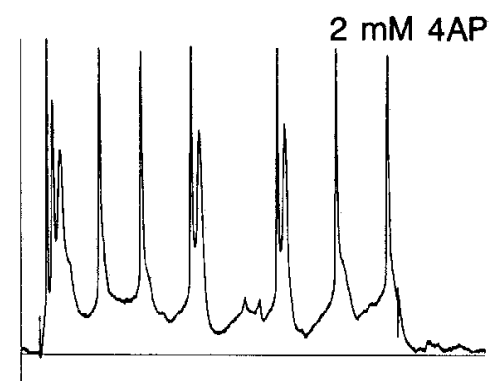

E
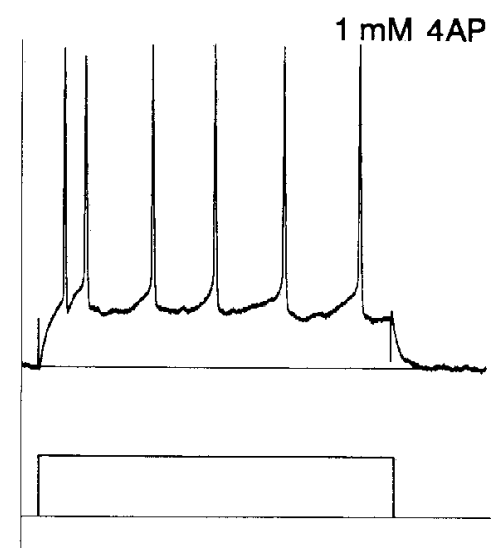

G

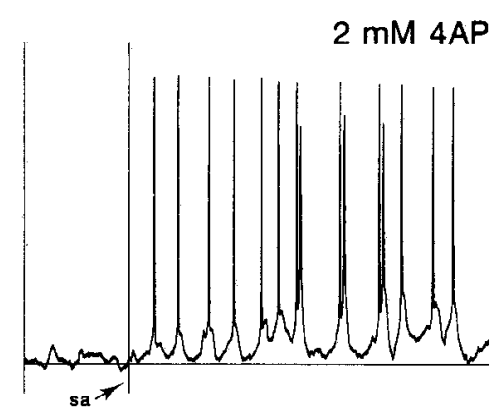

B

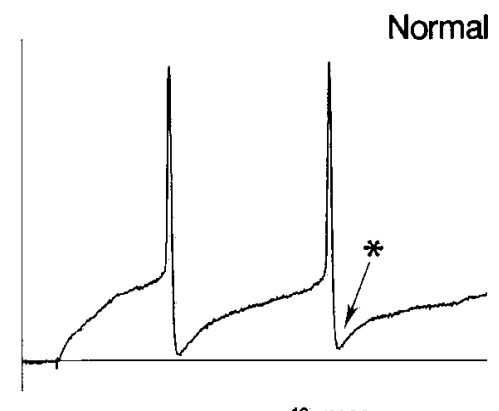

D

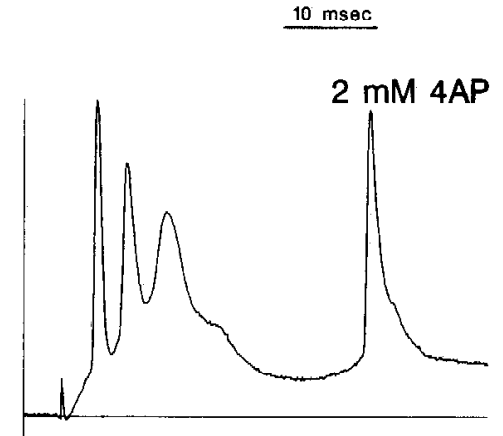

F
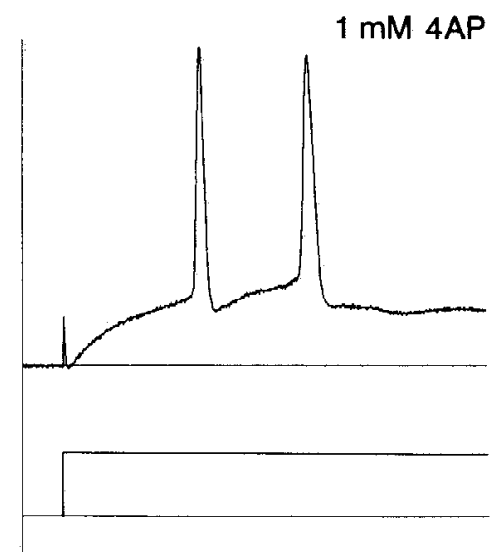

$\mathrm{H}$

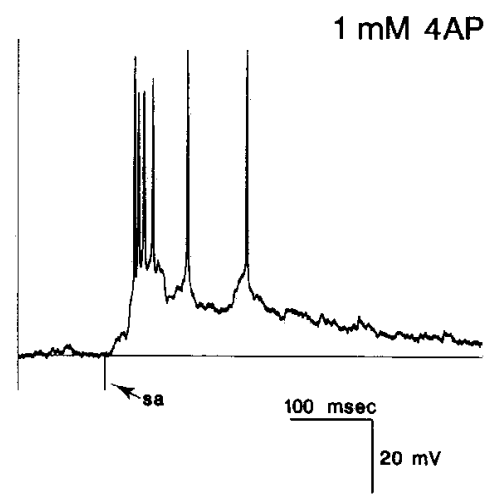

Figure 7. Action of 4-AP on cell response. $A$, Suprathreshold response of a cell to a $200 \mathrm{msec}$ depolarizing current pulse. $B$, Initial $50 \mathrm{msec}$ of the response shown in $A$. Asterisk indicates early postspike afterhyperpolarization. $C$, Response of the same cell to a $200 \mathrm{msec}$ pulse of the same duration and amplitude as in $A$ during bath application of 4-AP. $D$, Initial $50 \mathrm{msec}$ of the response shown in $C$. $E$, Response of a second cell to the same $200 \mathrm{msec}$ pulse during bath application of 4-AP. $F$, Initial 50 msec of the response shown in $E$. $G$, Repetitive firing of the first cell to shock stimulation of the CoIC while in 4-AP. $H$, PDS response of the second cell to stimulation of the CoIC during 4-AP application. Lower trace in $E$ represents the timing of the current pulse eliciting the responses in $A, C$, and $E$. Lower trace in $F$ represents the timing of the current pulse eliciting the responses in $B, D$, and F. sa, shock artifact. Voltage calibration in $H$ applies to all traces. Time calibration in $A$ applies to $A, C$, and $E$; time calibration in $B$ applies to $B, D$, and $F$; time calibration in $H$ applies to $G$ and $H$.
DC or in that portion of the EC immediately adjacent to the DC. The cell somata varied in size from $10 \times 11$ to $18 \times 26$ $\mu \mathrm{m}$ and were all situated $100-300 \mu \mathrm{m}$ from the tectal surface, corresponding to deep layer 1, layer 2, and superficial layer 3 of the cortex as defined by Faye-Lund and Osen (1985).

The dendritic trees were typically multipolar (Figs. 9, 10; see also Fig. 13), sending branches into all three cortical layers. Branches invading layer 1 would often extend to the very surface of the cortex. In the coronal plane, the dendritic fields of these cells could vary considerably in extent, ranging from a few hundred microns to over $800 \mu \mathrm{m}$ in diameter. The dendrites were typically moderately or sparsely spiny, but in three cases the 
Figure 8. Other synaptic inputs. A, Synaptic response to shock stimulation of the CoIC (upper trace) and LL (lower trace) while the cell was depolarized slightly to elucidate IPSPs. $B$, Synaptic response of the same cell $5 \mathrm{~min}$ after bath application of picrotoxin to the same shock stimuli as in $A$. $C$, PDS response to the same shock stimuli 20 min after addition of picrotoxin. $D$, Synaptic response of another cell to shock stimulation of the CoIC (upper trace), the ICC (middle trace), and the LL (lower trace) while the cell was depolarized slightly. $E$, Synaptic response of the same cell to the same stimuli 5 min after bath application of picrotoxin. $F$, Synaptic response $15 \mathrm{~min}$ after bath application of picrotoxin. $s a$, shock artifact. Calibration in $C$ applies to all traces.

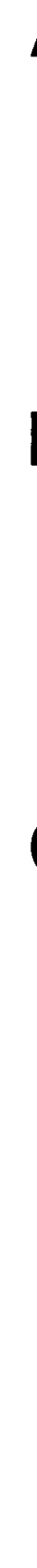
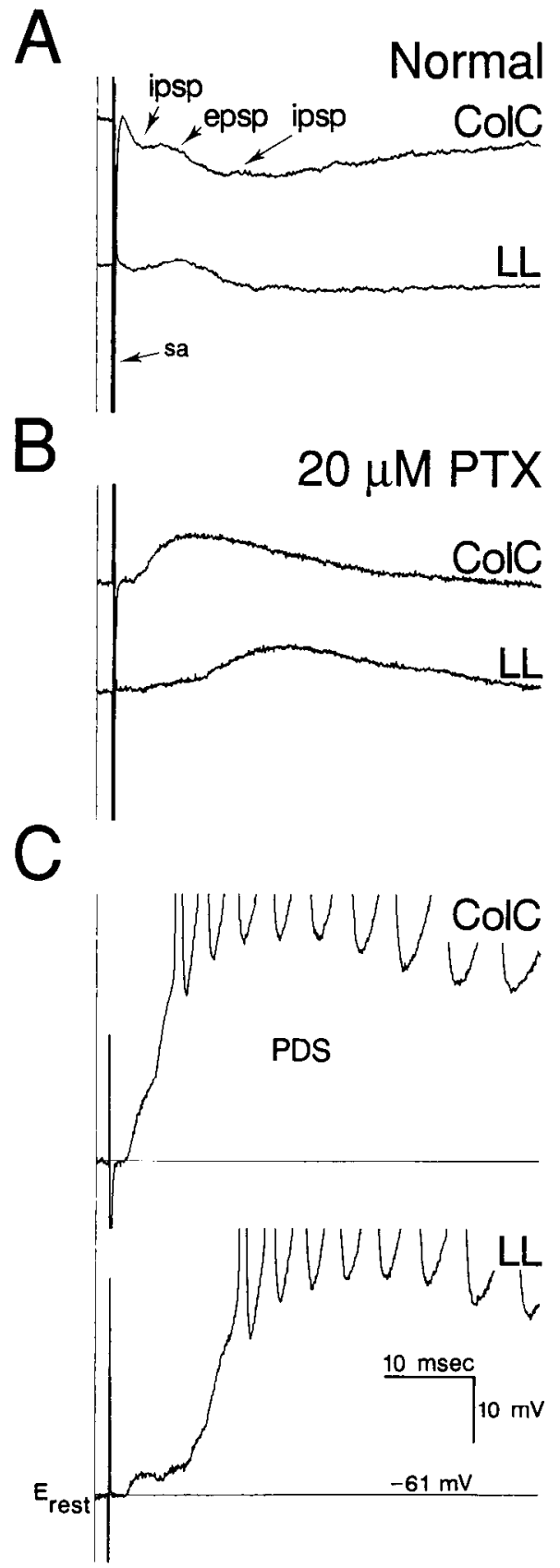
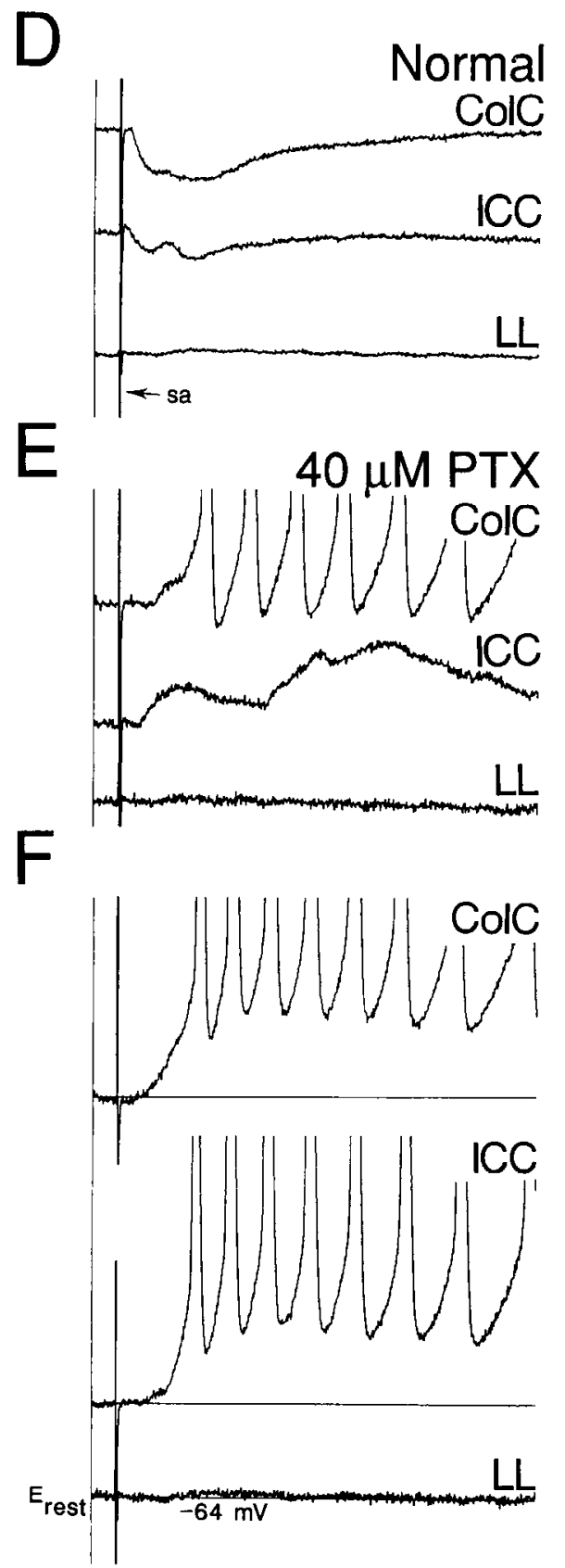

dendritic tree was almost aspinous. Because these cells were well filled with the neurobiotin tracer, it is not likely that this variation is a result of inadequate filling. The axon always arose from the cell body or a proximal dendrite. Despite the fact that slice thickness limits the amount of axon that can be recovered, the axon of many of the cells could be followed for considerable distances. Typically the axon would give off numerous collaterals that would branch extensively in all layers of the cortex (Figs. 11-13). These branches appeared to innervate regions of the cortex in close proximity to the cell of origin as well as cortical areas some distance away. Typically, only a few or none of the collaterals would venture outside the boundaries of cortex, into the ICC. When it could be distinguished, the main axon often headed laterally around the perimeter of the cortex, toward the brachium, which contains fibers connecting the IC and other auditory centers including the medial geniculate nucleus. Four of the injected cells had axons that instead projected medially into the CoIC (Fig. 11) but could only be followed a short distance after crossing the midline before being cut off at the top or bottom of the slice.

\section{Discussion}

Summary of results

In this article, I describe some of the physiological, pharmacological, and anatomical characteristics of a group of cells in the DC and the dorsal portion of the EC of the IC. The cells described in this article usually responded to depolarizing current pulses of increasing intensity with phasic spiking and then, as level increased, tonic spiking that showed rate adaptation. An offset response could also be elicited at the end of a hyperpolarizing pulse. The temporal aspects of this spiking behavior 


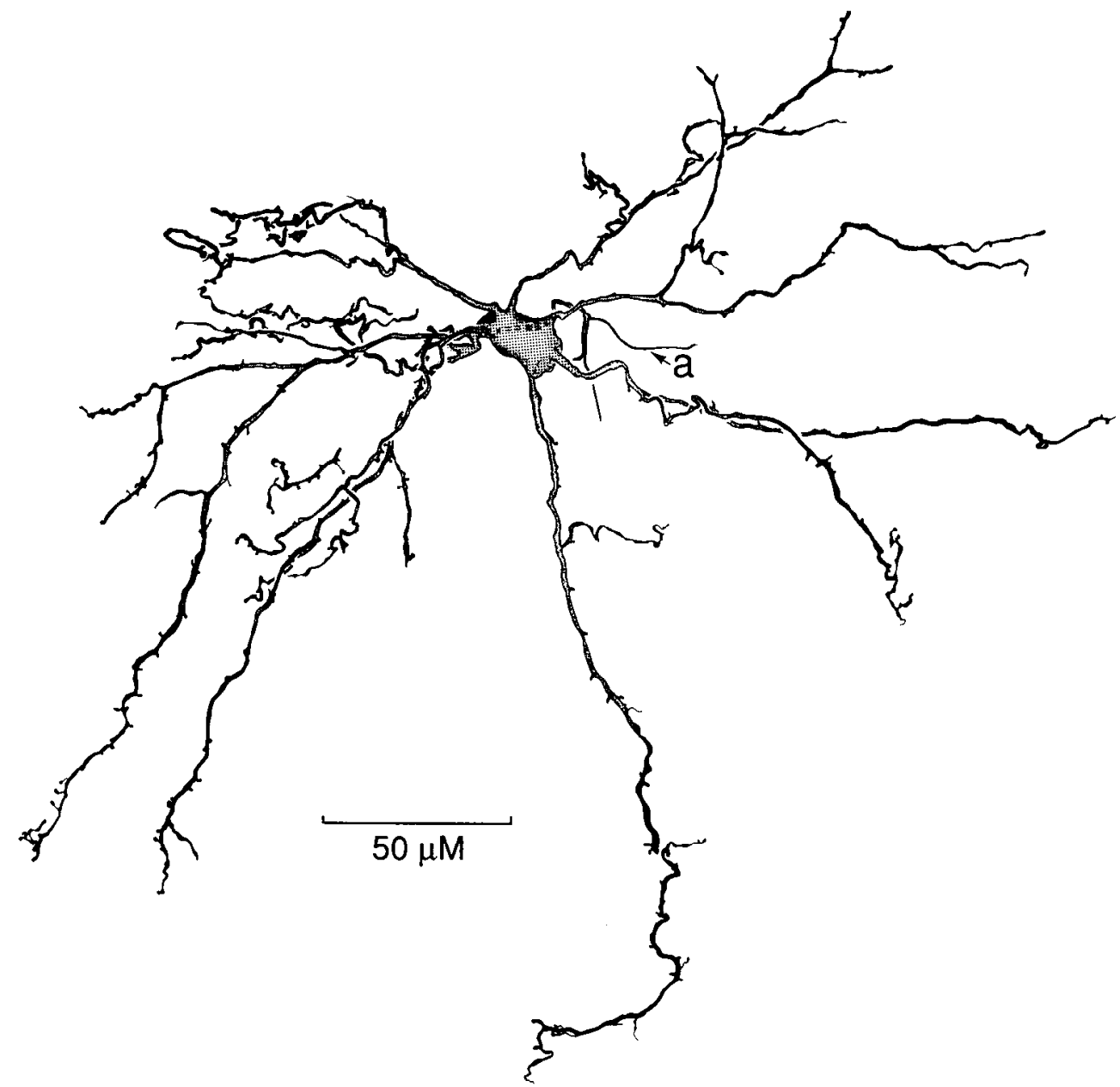

Figure 9. Camera lucida drawing of a neurobiotin-injected multipolar cell body and dendritic tree. Only the initial portion of the axon $(a)$ is illustrated. Dotted line on cell body indicates the course of axon, behind the cell body, from its point of origin at the left side. was largely dependent on activation of calcium conductances. Under appropriate conditions, these cells could also show calcium spikes. Stimulation of the ColC generated a consistent IPSP/EPSP/IPSP sequence. Stimulation of the LL usually elicited no synaptic response or a small-amplitude response with a longer latency. The sign, amplitude, and latency of the response were inconsistent from cell to cell. Stimulation of the ICC would often elicit a synaptic response but not in a consistent sequence.

Pharmacological experiments indicated that all shock-induced EPSPs are glutaminergic and use non-NMDA receptors under normal conditions. Longer EPSPs activated multisynaptically could be non-glutaminergic, but they must be driven by glutamate inputs from the CoIC because they were shut off in CNQX or DNQX. Shock-induced inhibition appears to be GABAergic and may be both direct and indirect. The late inhibition disappears in CNQX or DNQX and is thus probably taminergic axonal input from the CoIC.

Blocking $\mathrm{GABA}_{\mathrm{A}}$ with picrotoxin or bicuculline activates NMDA receptors, causing subsequent commissural stimulation to generate PDS behavior. Electrical stimulation of the ICC can also generate PDS activity, while stimulation of the LL rarely does. Shock-induced PDS activity in $0 \mathrm{Mg}^{2+}$ saline and in saline containing NMDA is further evidence that the PDS is elicited by activation of NMDA receptors. 4-AP also can evoke PDS behaviors, but it has not been determined whether this is because of activation of NMDA receptors.

Anatomically, the cells reported here are restricted to a narrow range of depths below the surface of the DC and dorsal reaches of the EC, adjacent to the DC. Their multipolar dendritic trees are moderately to sparsely spiny and traverse all layers of the cortex. Their axons generate numerous collaterals that primarily innervate the cortex, while their primary axon heads either around the outskirts of the colliculus toward the brachium or into the commissure.

\section{Inputs to the IC cortex - the CoIC}

What are the possible sources of the axons within the CoIC that might generate the observed shock-induced synaptic events? A variety of studies have utilized retrograde and anterograde tracer methods to determine the sites that project to the DC and EC of the IC. Unfortunately, descriptions of the course of the axons into the cortical regions are usually not provided. Two regions are known to use the CoIC to innervate the collicular cortex. Cells in the ICC, DC, and EC of the opposite IC are probably one of the major sources of axons that cross the midline to innervate both the contralateral DC and EC (Druga and Syka, 1984; Tokunaga et al., 1984; Faye-Lund and Osen, 1985; Coleman and Clerici, 1987). Similar methods have shown that layer $\mathrm{V}$ pyramidal cells of the primary auditory and surrounding cerebral cortical areas have a strong collicular input (Syka et al., 1980; Druga and Syka, 1984; Land et al., 1984; LeDoux et al., 1985; Coleman and Clerici, 1987; Games and Winer, 1988; Roger and Arnault, 1989; Herbert et al., 1991). Axons of these cells enter the ipsilateral IC via the brachium and synapse pri- 


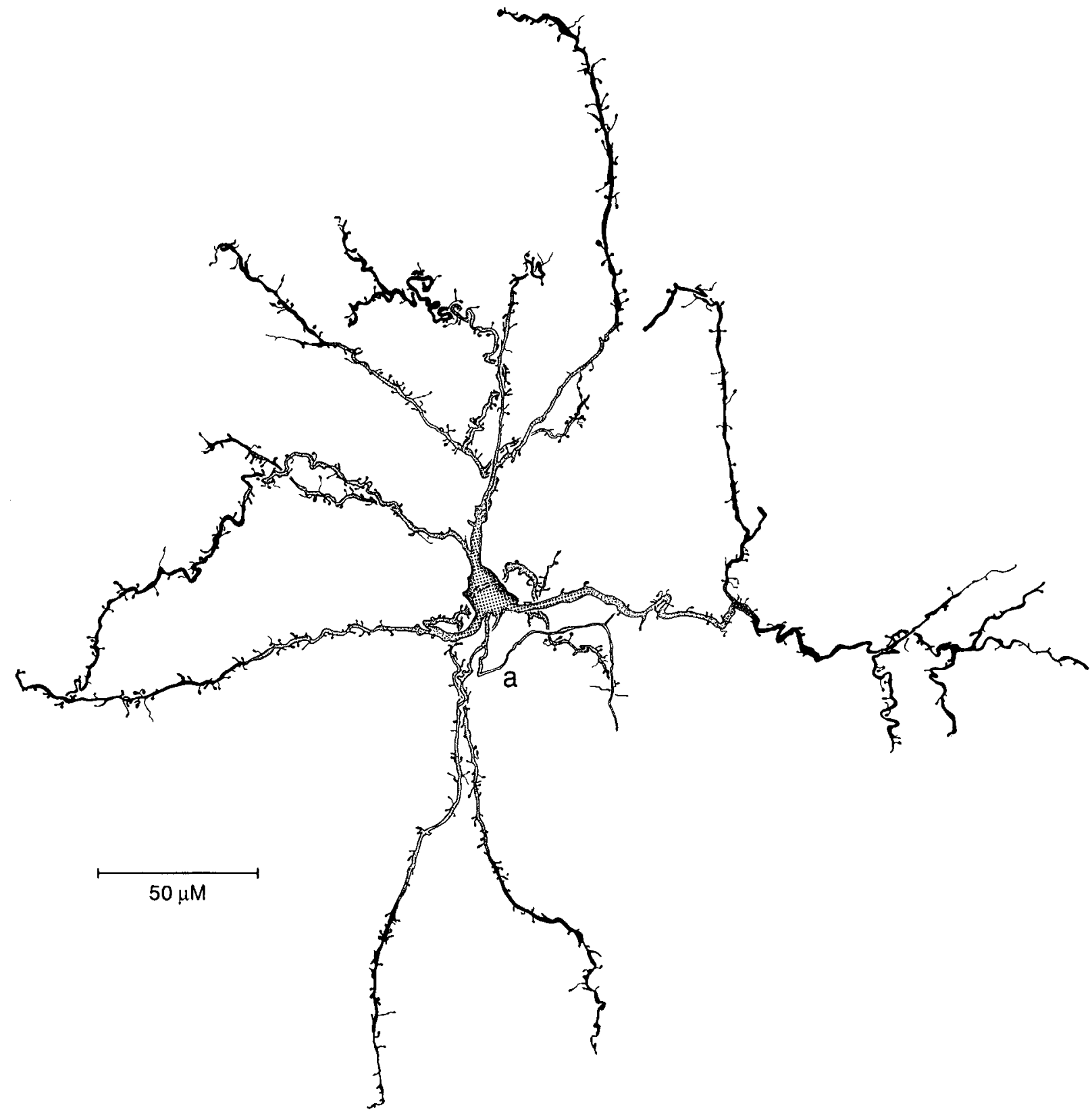

Figure 10. Camera lucida drawing of another neurobiotin-injected multipolar cell body and dendritic tree. Only the initial portion of the axon (a) is illustrated.

marily in the ipsilateral collicular cortex. Some of these fibers continue through the CoIC and terminate in the contralateral DC. Studies in the cat showed these corticocollicular terminals to be of the type I variety and potentially glutaminergic (Rockel and Jones, 1973; Adams and Wenthold, 1979).

\section{Inputs to IC cortex $-L L$ and ICC}

Anatomical evidence indicates that there is only a scant direct projection of lower auditory brainstem structures onto the collicular cortex, especially to the DC and more dorsally situated regions of the $\mathrm{EC}$ where the cells described here were located (Druga and Syka, 1984; Coleman and Clerici, 1987). EC and DC regions receive minor inputs from the contralateral dorsal and ventral cochlear nucleus and ipsilateral dorsal nucleus of the $L L$. In addition, the ventral nucleus of the $L L$ and superior paraolivary nucleus send a small projection to DC. Thus, it is not surprising that electrical stimulation of the LL rarely evoked rapid synaptic events in intracellular records.

Small gross injections indicate that both the DC and EC receive an input from the ICC on the same side. Occasionally, one set of stimulating electrodes was moved into the ICC, but a consistent set of electrically evoked synaptic events was not evoked from this region. This is probably not unexpected given that electrical stimulation here would activate not only cells within the ICC but axons heading to the cortex from other sources through this area. Experiments are now underway in which cells, and not axons of passage, are directly activated via drop application of glutamate or glutamate analogs: such studies should help to clarify the inputs from the ICC. 


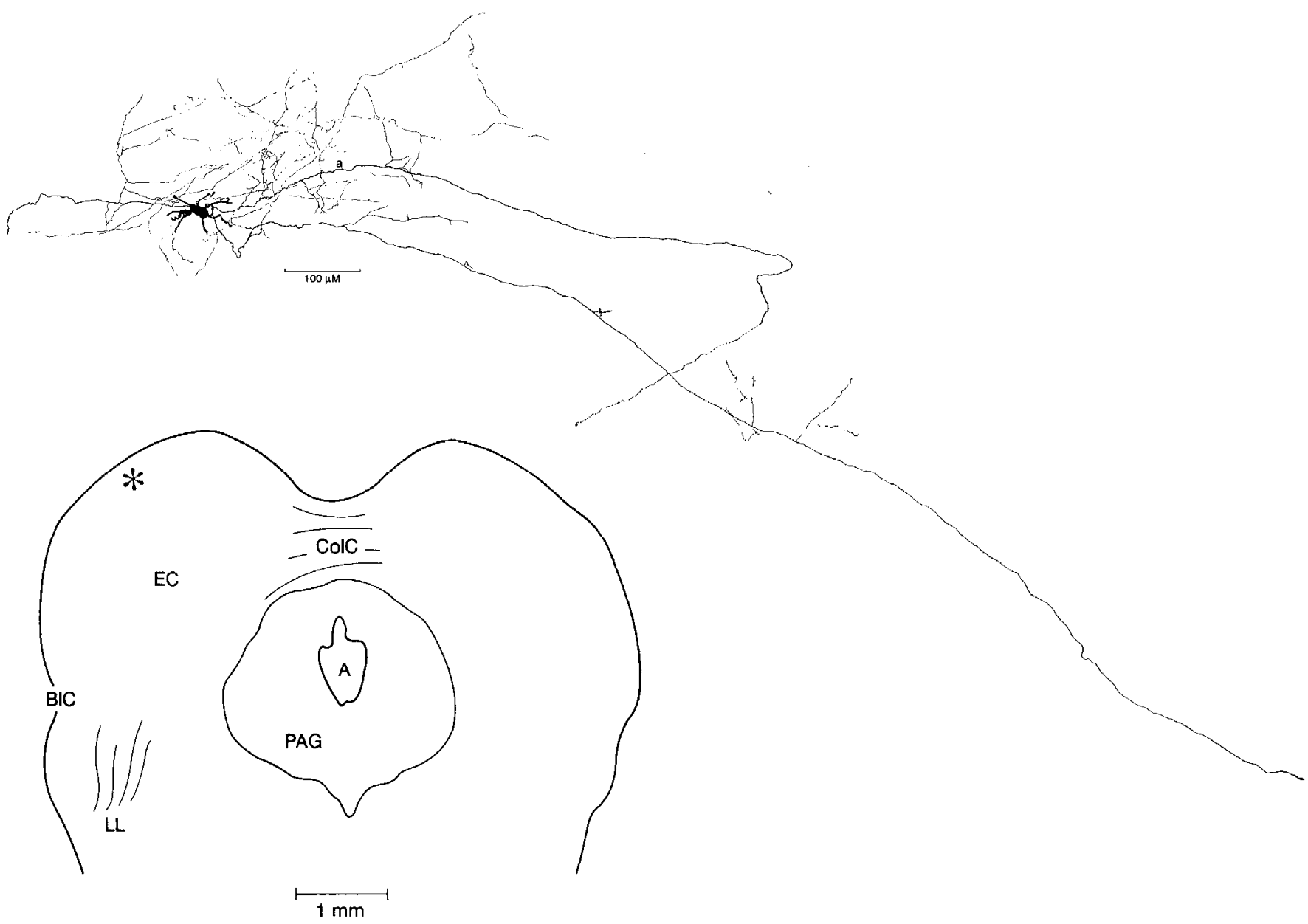

Figure 11. Camera lucida drawing of the same cell seen in Figure 9 showing the axonal (a) branching pattern, the cell body, and proximal dendrites. Distal dendrites are not shown to more clearly illustrate the axon collaterals. Inset, Camera lucida drawing showing the location of the cell (asterisk) in the EC, $A$, cerebellar aqueduct; $B I C$, brachium of the $\mathrm{IC} ; P A G$, periaqueductal gray.

\section{Activation of NMDA receptors and the PDS phenomenon}

The results presented here clearly demonstrate that the activation of a specific input to the collicular cortex is capable of eliciting large depolarizing events in cells when $\mathrm{GABA}_{\mathrm{A}}$ inhibition is reduced and/or NMDA receptors are activated. A similar PDS behavior may also be elicited in $\mathrm{O} \mathrm{Mg}^{2+}$ saline and normal saline containing 4-AP, circumstances predicted to facilitate activation of NMDA receptors and increase membrane excitability. PDSs have been described as the cellular hallmark of focal epileptogenesis (Prince, 1985), which, when they occur synchronously in a population of cells, generate the EEG abnormality known as the interictal spike. It is interesting to note that a number of studies have implicated the cortex of the IC as a potential site for audiogenic (sound-evoked) epileptic seizure initiation (see Wada et al., 1970; Ward, 1971; Henry et al., 1972; Laird and Huxtable, 1978; Willott and Lu, 1980; McGown et al., 1984, 1987; Browning, 1986). It is also interesting to note that the seizure susceptibility appears to be strongly linked to the integrity of GABAergic neurotransmission and the action of NMDA receptors in the IC, in audiogenic seizureprone states induced either (1) genetically as in the genetically epilepsy prone rat (GEPR), (2) through alcohol withdrawal, or (3) through intracollicular bicuculline or NMDA infusion (Duplisse et al., 1974; Frye et al., 1983, 1986; Faingold et al., 1986;
Millan et al., 1986; Meldrum et al., 1988; Browning et al., 1989). Some evidence exists that damage in the cochlea of the GEPR may be the underlying abnormality that ultimately leads to seizure susceptibility (Penny et al., 1986). This argument is strengthened by the observation of Pierson and Swann (1988) that normal rats can be made permanently seizure susceptible by administration of the cochleotoxic antibiotic kanamycin at a precise stage of development. How a cochlear abnormality might induce a collicular abnormality capable of seizure initiation poses intriguing developmental questions.

It has long been emphasized, in interpreting experimentation on cortical and hippocampal models of epilepsy (scc Ayala ct al., 1973), that an actual seizure event does not occur until interictal spikes occur so closelv together that they appear to "merge" while at the same time the underlying PDS becomes much more prolonged. In the experiments described here, recording from cells in IC cortex of hooded rat older than $21 \mathrm{~d}$ of age, and in a similar preparation using the guinea pig IC (Smith, 1986), PDS durations greater than $400 \mathrm{msec}$ have never been observed. In contrast, Pierson and Swann (1988) show much more prolonged, ictal-like excitatory events in IC cortex cells in slices when $\mathrm{GABA}_{\mathrm{A}}$ inhibition was blocked in ways similar to those described here. The slices in this report were taken from rats of an unspecified variety from 13-15 d of age. Likewise, my recordings from cells in IC slices taken from GEPRs 


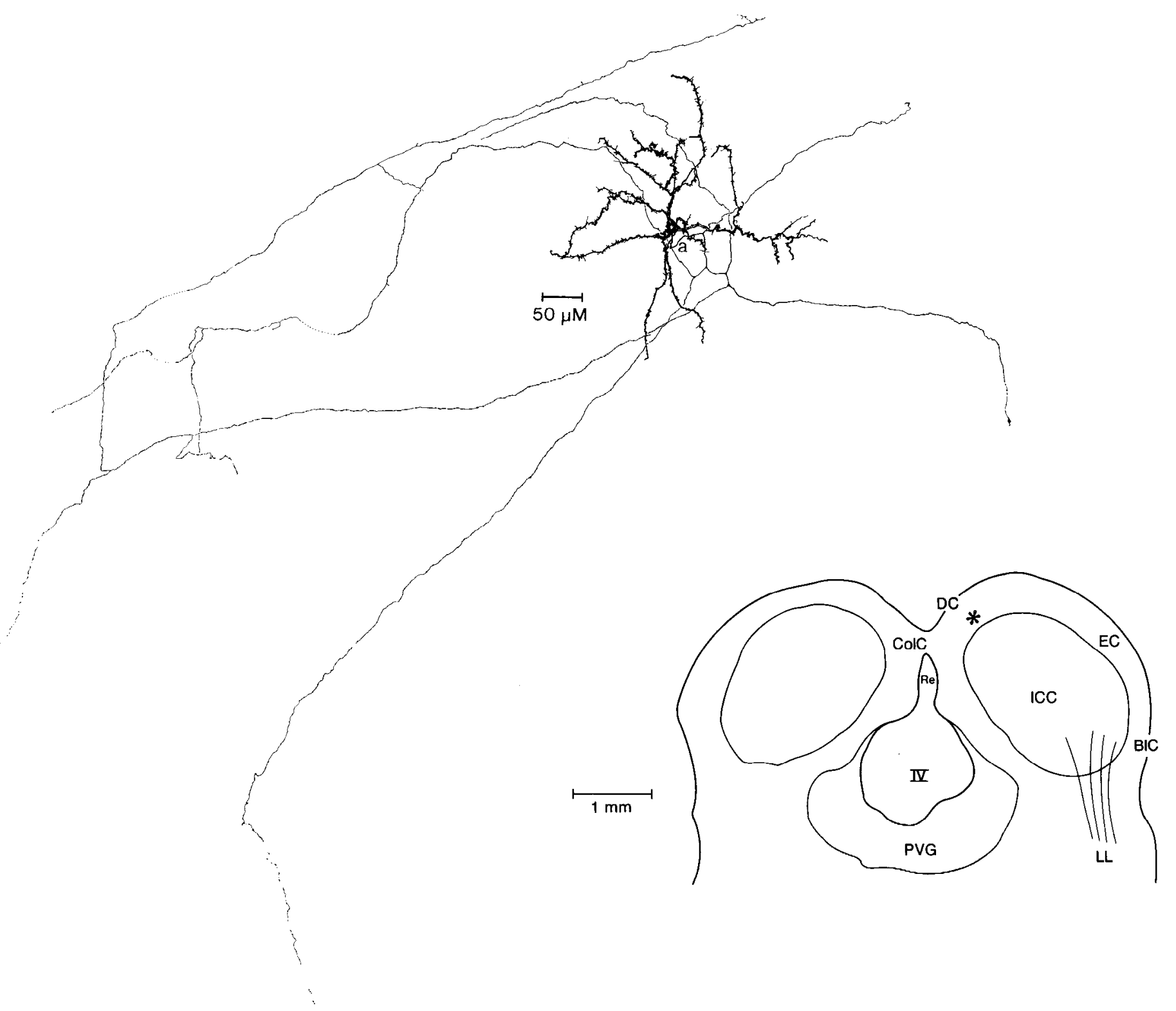

Figure 12. Camera lucida drawing of the same cell seen in Figurc 10 with the axonal branching pattern included (a, axon). Inset, Camera lucida drawing of the section containing the cell body of this cell. The cell soma location is indicated by the asterisk. BIC, brachium of the IC; $I V$, fourth ventricle; $P V G$, periventricular gray; $R e$, recess.

(GEPR9s; P. H. Smith, unpublished observations) older than $20 \mathrm{~d}$ of age can show substantially prolonged, ictal-like events when $\mathrm{GABA}_{\mathrm{A}}$ inhibition was blocked or NMDA receptors activated. Perhaps a mechanism that is present in very young animals, which facilitates ictal-like events, is downregulated as normal animals mature but not as the GEPR matures.

It is intriguing that one of the most striking anatomical features of these cells is the large number of axon collaterals they display. Their tendency to remain largely confined to the cortex region of the colliculus indicates that a large amount of interaction is going on between cells in the area. Certainly, a significant degree of excitatory synaptic coupling among members of a neuronal population can be an essential feature in the development of the giant synaptic PDS behavior seen within cortical structures under seizure-prone conditions (Prince, 1985). The use of such complex interconnections under normal conditions is more difficult to discern but might be elucidated by recording from two cortical cells simultaneously with separate electrodes, to determine the sign, strength, and frequency of interaction.

It is still unclear how abnormal activity in the IC cortex might escape the colliculus to initiate a motor output manifested as a convulsion. Lesions of auditory structures rostral to the IC fail to prevent convulsions, indicating that descending collicular pathways may carry the requisite convulsive output (see Browning, 1986). Lesions of the substantia nigra have been shown to reduce audiogenic seizure intensity significantly, but there are no known projections from IC cortex to this structure. Rather, cells in substantia nigra pars lateralis project to the IC cortex (Olazabal and Moore, 1989). It is presumably the loss of this primarily GABAergic input to the colliculus that can alter the activity in the audiogenic seizure pathway out of the IC. GABAergic nigral input from pars reticulata to the superior collic- 


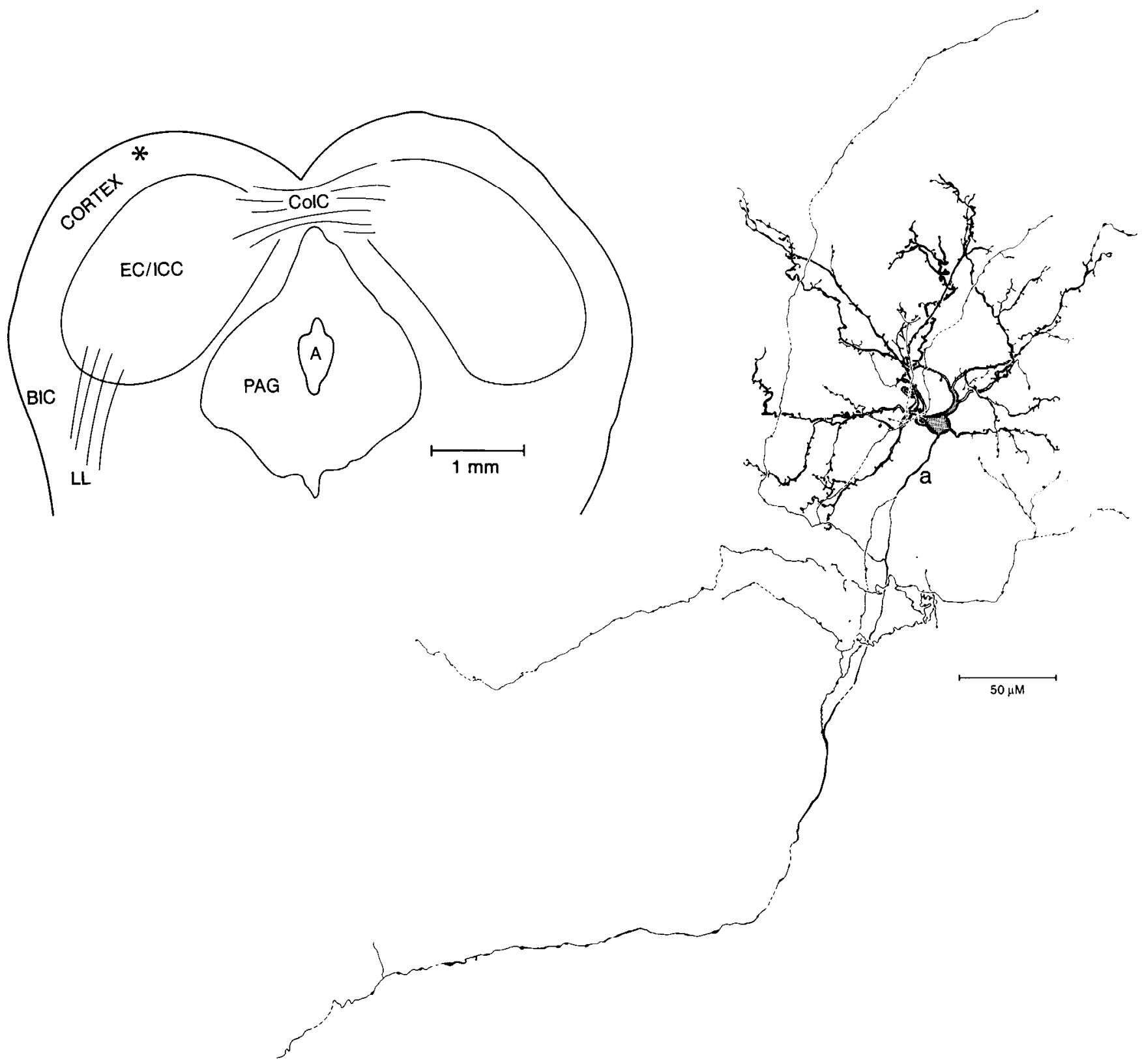

Figure 13. Right, Camera lucida drawing of another neurobiotin-labeled cell body, dendritic tree, and axon (a). Left, Camera lucida drawing showing the location of the cell (asterisk) in a transition region between the DC and EC. $A$, cerebral aqueduct; $B I C$, brachium of the IC; $P A G$, periaqueductal gray.

ulus has been shown to have anticonvulsant effects in a number of seizure models (Iadarola and Gale, 1982; Dean and Gale, 1989). Some IC cortical cells project to deep layers of the superior colliculus (Tokunaga et al., 1984; Coleman and Clerici, 1987) and may be involved in the circuit mediating the appropriate orientation of head, eyes, and pinna movements (see Aitkin, 1985). Lesion and stimulation studies of the deep superior colliculus indicate that IC output generating the major components of the seizure behavior probably does not use this route (Wada et al., 1970; McCown et al., 1984; Browning et al., 1985; Browning, 1986). Other cells in the IC cortex form a "descending" projection to the pons and medulla, and it is interesting to note that bilateral lesions of a region of the pons called nucleus reticularis pontis oralis (RPO) significantly attenuates audiogenic convulsions (Browning et al., 1985). This would seem to implicate this descending pathway in seizure initiation; however, RPO is not the pontine region where colliculopontine fibers terminate (Burne et al., 1981; Faye-Lund, 1986). Descending IC inputs to the medulla terminate primarily in periolivary nuclei, where they may act on olivocochlear cells that innervate the cochlea and/or the cochlear nucleus (FayeLund, 1986; Vetter and Saldana, 1990). Activation of such connections would presumably not evoke a gross motor response. Thus, the seizure output pathway remains obscure. The main axon of some of the cells I have injected headed into the CoIC for the contralateral IC. The majority headed laterally along the edge of the cortex, parallel to the surface, but could not be followed into the brachium or the LL, so it could not be determined whether they were components of the ascending or descending collicular output. 


\section{Activation of NMDA receptors and a simple learning circuit}

NMDA receptors have also been implicated in the phenomenon of long-term potentiation (LTP), a process that may underlie some forms of learning and memory (see Nicoll et al., 1988). In their investigations of the classical conditioning of emotional responses to auditory stimuli, LeDoux and his colleagues have shown that cells in the collicular cortex are involved in this emotional learning circuit (LeDoux et al., 1985, 1986, 1987, 1988, 1990a,b; Iwada et al., 1986a,b). It has been proposed that the learning that takes place in this paradigm may occur in the amygdala or medial geniculate, where LTP has been demonstrated (Ryugo and Weinberger, 1976; Gerren and Weinberger, 1983; Clugnet and LeDoux, 1989). The presence of NMDA receptors in the IC cortex that has been demonstrated here may also be utilized in this simple learned behavior.

Many interesting and potentially important and answerable questions have arisen from this study. For example, (1) what are the response properties of similar cells in brain slices taken from the GEPR rat? Preliminary results suggest intriguing differences. (2) Do all cells projecting to a given efferent termination site of the cortex share similar properties? One method that might determine this would be by injection of a retrograde label, such as rhodamine beads (Katz, 1987), into a target region of IC cortex. Subsequent recordings from rhodamine-labeled cells in IC slices of these animals would help to determine if a particular population of cells displayed unique response features such as PDS behavior. (3) Do dual intracellular recordings from two cells in the cortex reveal a high degree of excitatory or inhibitory interconnection? (4) Do other cells in other regions of the colliculus, for example the ICC, display unique features? (4) Given their involvement in the conditioned fear circuit and the presence of NMDA receptors, can cells in the cortex display associative-style LTP when multiple inputs are stimulated in the appropriate temporal sequence?

\section{References}

Adams JC (1981) Heavy metal intensification of DAB-based HRP reaction product. J Histochem Cytochem 29:775.

Adams JC, Wenthold RW (1979) Distribution of putative amino acid transmitters, choline acetyltransferase and glutamate decarboxylase in the inferior colliculus. Neuroscience 4:1947-1951.

Aghajanian GK, Rasmussen K (1989) Intracellular studies in the facial nucleus illustrating a simple new method for obtaining viable motoneurons in adult rat brain slices. Synapse 3:331-338.

Aitkin L (1985) The auditory midbrain: structure and function in the central auditory pathway. Clifton, NJ: Humana.

Ayala GF, Dichter M, Gumnit RJ, Matsumoto H, Spencer WA (1973) Genesis of epileptic interictal spikes: new knowledge of cortical feedback systems suggests a neurophysiological explanation of brief paroxysms. Brain Res 52:1-17.

Browning RA (1986) Neuroanatomical localization of structures responsible for seizures in the GEPR: lesion studies. Life Sci 39:857867.

Browning RA, Nelson DK, Mogharreban N, Jobe PC, Laird HE II (1985) Effect of midbrain and pontine tegmental lesions on audiogenic seizures in genetically epilepsy-prone rats. Epilepsia 26:175183.

Browning RA, Lanker ML, Faingold CL (1989) Injections of noradrenergic and $\mathrm{GABAergic}$ agonists into the inferior colliculus: effects on audiogenic seizures in genetically epilepsy prone rats. Epilepsy Res 4:119-125.

Burne RA, Azizi SA, Mihailoff GA, Woodward DJ (1981) The tectopontine projection in the rat with comments on visual pathways to the basilar pons. J Comp Neurol 202:287-307.

Clopton BM, Silverman MS (1977) Plasticity of binaural interaction. II. Critical period and changes in midline response. J Neurophysiol 40:1275-1280.
Clopton BM, Winfield JA (1973) Tonotopic organization of the inferior colliculus of the rat. Brain Res 56:355-358.

Clugnet MC, LeDoux JE (1989) Long term potentiation (LTP) in the lateral amygdala (AL) in response to stimulation of the medial geniculate body (MGB). Soc Neurosci Abstr 15:891.

Coan EJ, Collingridge GL (1985) Magnesium ions block an $N$-methylD-aspartate receptor-mediated component of synaptic transmission in rat hippocampus. Neurosci Lett 53:21-26.

Coleman JR, Clerici WJ (1987) Sources of projections to subdivisions of the inferior colliculus of the rat. J Comp Neurol 262:215-226.

Dean P, Gale K (1989) Anticonvulsant action of GABA receptor blockade in the nigrotectal target region. Brain Res 477:391-395.

Druga R, Syka J (1984) Ascending and descending projections to the inferior colliculus in the rat. Physiol Bohemoslov 33:31-42.

Duplisse BR, Picchioni L, Chin L, Consroe PF (1974) Relationship of the inferior colliculus and gamma-aminobutyric acid (GABA) to audiogenic seizures in the rat. Fed Proc 33:468.

Faingold CL, Gehlbach G, Travis MA, Caspary DM (1986) Inferior colliculus neuronal response abnormalities in genetically epilepsy prone rats: evidence for a deficit of inhibition. Life Sciences 39:869-879.

Faingold CL, Hoffman WE, Caspary DM (1989) Effects of excitatory amino acids on acoustic responses of inferior colliculus neurons. Hearing Res 40:127-136.

Farley GR, Morley BJ, Javel E, Gorga MP (1982) Single-unit responses in the rat inferior colliculus during iontophoreses of cholinergic agents. Soc Neurosci Abstr 8:348.

Faye-Lund H (1985) The neocortical projection to the inferior colliculus in the albino rat. Anat Embryol 173:53-70.

Faye-Lund $H$ (1986) Projection from the inferior colliculus to the superior olivary complex in the albino rat. Anat Embryol 175:35-52.

Faye-Lund H, Osen KK (1985) Anatomy of the inferior colliculus of the rat. Anat Embryol 171:1-20.

Frye GD, McCown TJ, Breese GR (1983) Characterization of susceptibility to audiogenic seizures in ethanol-dependent rats after microinjection of gamma-aminobutyric acid (GABA) agonists into the inferior colliculus, substantia nigra or medial septum. J Pharmacol Exp Ther 227:663-670.

Frye GD, McCown TJ, Breese GR, Peterson SL (1986) GABAergic modulation of inferior colliculus excitability: role in ethanol withdrawal audiogenic seizures. J Pharmacol Exp Ther 237:478-485.

Games KD, Winer JA (1988) Layer V in rat auditory cortex: projections to the inferior colliculus and contralateral cortex. Hearing Res 34:1-26.

Gerren RA, Weinberger NM (1983) Long term potentiation in the magnocellular medial geniculate nucleus of the anesthetized cat. Brain Res 265:138-142.

Gutnick MJ, Conners BW, Prince DA (1982) Mechanisms of neocortical epileptogenesis in vitro. J Neurophysiol 48:1321-1335.

Hashikawa T (1983) The inferior colliculopontine neurons of the cat in relation to other collicular descending neurons. J Comp Neurol 219:241-249.

Henry KR, Wallick M, Davis M (1972) Inferior colliculus lesions: effects on audiogenic seizure and preyer reflex. Physiol Behav 9:885887.

Herbert H, Aschoff A, Ostwald J (1991) Topography of projections from the auditory cortex to the inferior colliculus in the rat. J Comp Neurol 304:103-122.

Iadarola MJ, Gale K (1982) Substantia nigra: site of anticonvulsant activity mediated by gamma-aminobutyric acid. Science $218: 1237-$ 1240.

Inagaki N, Toda $\mathrm{K}$, Taniuchi I, Panula $\mathrm{P}$, Yamatodani A, Tohyama M, Watanabe T, Wada H (1990) An analysis of histaminergic efferents of the tuberomammillary nucleus to the medial preoptic area and the inferior colliculus in the rat. Exp Brain Res 80:374-380.

Iwada J, LeDoux IE, Reis DJ (1986a) Destruction of neurons in the lateral hypothalamus disrupts cardiovascular but not behavioral conditioned emotional responses. Brain Res 368:161-166.

Iwada J, LeDoux JE, Meeley MP, Arneric S, Reis DJ (1986b) Intrinsic neurons in the amygdaloid field projected to by the medial geniculate body mediate emotional responses conditioned to acoustic stimuli. Brain Res 383:195-214.

Katz LC (1987) Local circuitry of identified projection neurons in cat visual cortex brain slices. J Neurosci 7:1223-1249.

Laird HE, Huxtable RJ (1978) Taurine and audiogenic epilepsy. In: Taurine and neurological disorders (Barbeau A, Huxtable RJ, eds), pp 339-357. New York: Raven. 
Land PW, Rose LL, Harvey AR, Liverman SA (1984) Neonatal auditory cortical lesions result in aberrant crossed cortico-tectal and cortico-thalamic projections in rats. Dev Brain Res 12:126-130.

LeDoux JE, Ruggiero DA, Reis DJ (1985) Projections to the subcortical forebrain from anatomically defined regions of the medial geniculate body of the rat. J Comp Neurol 242:182-213.

LeDoux JE, Sakaguchi A, Iwada J, Reis DJ (1986) Interuptions of projections from the medial geniculate body to the archineostriatal field disrupts the classical conditioning of emotional responses to acoustic stimuli. Neuroscience 17:615-627.

LeDoux JE, Ruggierio DA, Forrest R, Stornetta R, Reis DJ (1987) Topographic organization of convergent projections to the thalamus from the inferior colliculus and spinal cord in the rat. J Comp Neurol 264:123-146.

LeDoux JE, Iwata J, Cicchetti P, Reis DJ (1988) Different projections of the central amygdaloid nucleus mediate autonomic and behavioral correlates of conditioned fear. J Neurosci 8:2517-2529.

LeDoux JE, Farb C, Rurriero DA (1990a) Topographic organization of neurons in the acoustic thalamus that project to the amygdala. $J$ Neurosci 10:1043-1054.

LeDoux JE, Cicchetti P, Xagoraris A, Romanski LM (1990b) The lateral amygdaloid nucleus: sensory interface of the amygdala in fear conditioning. J Neurosci 10:1062-1069.

McCown TJ, Greenwood RS, Frye GD, Breese GR (1984) Electrically elicited seizures from the inferior colliculus: a potential site for the generation of epilepsy. Exp Neurol 86:526-534.

McCown TJ, Greenwood RS, Breese GR (1987) Inferior collicular interactions with limbic seizure activity. Epilepsia 28:234-241.

Meldrum B, Millan M, Patel S, deSarro G (1988) Anti-epileptic effects of focal micro-injections of excitatory amino acid antagonists. J Neural Transm 72:191-200.

Millan M, Meldrum BS, Faingold CL (1986) Induction of audiogenic seizure susceptibility by focal infusion of excitant amino acids or bicuculline into the inferior colliculus of normal rats. Exp Neurol 91: 634-639.

Moller AR, Rees A (1986) Dynamic properties of the responses of single neurons in the inferior colliculus of the rat. Hearing Res 24: 203-315.

Nicoll RA, Alger BE (1981) A simple chamber for recording from submerged brain slices. J Neurosci Methods 4:153-156.

Nicoll RA, Kauer JA, Malenka RC (1988) The current excitement in long-term potentiation. Neuron 1:97-103.

Olazabal UE, Moore JK (1989) Nigrolectal projection to the inferior colliculus: horseradish peroxidase transport and tyrosine hydroxylase immunohistochemical studies in rats, cats, and bats. J Comp Neurol 282:98-118.

Penny JE, Brown RD, Wallace MS, Henley CM (1986) Auditory aspects of seizure in the genetically epilepsy prone rat. Life Sci 39:887895.

Pierson MG, Swann JL (1988) The sensitive period and optimum dosage for induction of audiogenic seizure susceptibility by kanamycin in the Wistar rat. Hearing Res 32:1-10.

Pierson MG, Smith KL, Swann JW (1989) A slow NMDA-mediated synaptic potential underlies seizures originating from midbrain. Brain Res 486:381-386.

Poon PWF, Chen X, Hwang JC (1990) Altered sensitivities of auditory neurons in the rat midbrain following early postnatal exposure to patterned sounds. Brain Res 524:327-330.

Poon PWF, Chen X, Hwang JC (1991) Basic determinants for FM responses in the inferior colliculus of rats. Exp Brain Res 83:598606.

Prince DA (1985) Physiological mechanisms of focal epileptogenesis. Epilepsia 26[Suppl 1]:S3-S14.

Reale RA, Glaser EM (1975) Tone burst and sweep tone responses of single units in the inferior colliculus of the unanaesthetized-paralyzed albino rat. Soc Neurosci Abstr 1:38.

Rockel AJ, Jones EG (1973) Observations on the fine structure of the central nucleus of the inferior colliculus of the cat. J Comp Neurol 147:61-92.

Roger M, Arnault P (1989) Anatomical study of the connections of the primary auditory area in the rat. J Comp Neurol 287:339-356.

Ryugo DK (1977) The role of the afferent fiber systems on the development and differentiation of the inferior colliculus. Soc Neurosci Abstr 3:30.

Ryugo DK, Weinberger NM (1976) Differential plasticity of morphologically distinct neurons in the medial geniculate body of the cat during classical conditioning. Soc Neurosci Abstr 2:435.

Saldana E (1990) The rat colliculo-olivary projection is tonotopic. Soc Neurosci Abstr 16:716.

Schwartzkroin PA, Prince DA (1980) Changes in excitatory and inhibitory synaptic potentials leading to epileptic activity. Brain Res 183:61-76.

Silverman MS, Clopton BM (1977) Plasticity of binaural interaction. II. Effects of early auditory deprivation. J Neurophysiol 40:12661274.

Smith PH (1986) Synaptic responses of neurons in brain slices of the guinea pig inferior colliculus. IUPS Satellite Symposium on Hearing, University of California, San Francisco, CA, p 82.

Syka J, Druga R, Popelar J, Kalinova B (1980) Functional organization of the inferior colliculus. In: Neuronal mechanisms of hearing (Syka J, Aitkin LM, eds), pp 137-153. New York: Plenum.

Tanaka K, Otani K, Tokunaga A, Sugita S (1985) The organization of neurons in the nucleus of the lateral lemniscus projecting to the superior and inferior colliculi in the rat. Brain Res 341:252-260.

Tokunaga A, Sugita S, Otani K (1984) Auditory and non-auditory subcortical afferents to the inferior colliculus of the rat. J Hirnforsch 25:461-472.

Vetter DF, Saldana E (1990) Descending inputs from the central nucleus of the inferior colliculus to the medial olivocochlear system in the rat: a combined PHA-L and CT-HRP study. Soc Neurosci Abstr 16:716.

Wada JA, Teveo A, White B, Jung E (1970) Inferior colliculus lesion and audiogenic seizure susceptibility. Exp Neurol 28:326-382.

Ward R (1971) Unilateral susceptibility to audiogenic seizure impaired by contralateral lesions of the inferior colliculus. Exp Neurol 32:313316.

Willott JF, Lu SM (1980) Midbrain pathways of audiogenic seizures in DBA/2 mice. Exp Neurol 70:288-299.

Yasui Y, Kayahara T, Kuga Y, Katsuma N (1990) Direct projections from the globus pallidus to the inferior colliculus in the rat. Neurosci Lett 115:121-125. 